\title{
CANONICAL TYPOLOGY, SUPPLETION, AND POSSIBLE WORDS
}

\author{
Greville G. Corbett \\ University of Surrey
}

\begin{abstract}
I specify a typology for the extreme of inflectional morphology, namely suppletion (as in $g o$ $\sim$ went). This is an unusual enterprise within typology, and it requires a 'canonical' approach. That is, I define the canonical or best instance, through a set of converging criteria, and use this point in theoretical space to locate the various occurring types. Thus the criteria establish the dimensions along which specific instances of suppletion are found, allowing me to calibrate examples out from the canonical. The criteria fall into two main areas, those internal to the lexeme and those external to it. Moreover, I find interactions with other morphological phenomena and discuss four of them: syncretism, periphrasis, overdifferentiation, and reduplication. These remarkable instances of suppletion, particularly when in interaction with other phenomena, extend the boundary of the notion 'possible word'. Besides laying out the possibilities for the specific phenomenon of suppletion, I show how a canonical approach allows progress in typology, even in the most challenging areas.*
\end{abstract}

INTRODUCTION. If the examples were not so familiar, linguists would look harder at instances of suppletion, like go $\sim$ went and Russian rebenok 'child' $\sim$ deti 'children'. Such items are significant for our view of morphology (as Carstairs-McCarthy (1994: 4410) points out). They are also a limiting case for the notion POSSIBLE WORD, and as such they constitute a real challenge to the typologist. There have been several accounts of suppletion, starting with Osthoff 1899; an annotated bibliography of this work with over seventy items is provided by Chumakina (2004). However, the definitions and surveys proposed do not yet constitute a full typology. The focus of this article is therefore a specification of the criteria for a typology of suppletion. To propose a typology in this apparently hostile terrain means adopting a CANONICAL APPROACH, one that defines a principled point in the theoretical space and calibrates outwards from it.

I start by outlining the basic notions needed and then consider the place of suppletion. The heart of the article is the criteria for the typology, which divide naturally into two main types, those internal to the lexeme and those external to the lexeme. These are taken up in turn. In addition, I treat the question of interactions with other morphological phenomena, which extend further the notion possible word, and finally address the interesting issue of the frequency of suppletive items.

1. Overview of essential ideas.

1.1. The CANONICAL APPROACH IN TYPOLOGY. Typologists are tackling successively more difficult areas, and to continue doing so we need new methods. As part of this,

* The support of the AHRC under grant B/RG/AN4375/APN10619 and of the ESRC under grant RES051-27-0122 is gratefully acknowledged. Versions of the article were read at the Workshop on Paradigm Irregularities, University of Manchester, 10-11 April 2003; the Max Planck Institute for Evolutionary Anthropology, Leipzig, 25 July 2003; the Fourth Mediterranean Morphology Meeting (MMM4), Catania, 21-23 September 2003; the School of Oriental and African Studies, London, 21 October 2003; the Max Planck Institute for Psycholinguistics, Nijmegen, 21 January 2004; and the 6th biennial meeting of the Association for Linguistic Typology, Padang, 21-25 July 2005. I wish to thank members of each audience for useful discussion, and all the following for helpful comments or relevant references at different stages: Matthew Baerman, Jonathan Bobaljik, Melissa Bowerman, Penny Brown, Andrew Carstairs-McCarthy, Bernard Comrie, Östen Dahl, Matthew Dryer, Nicholas Evans, Alexander Krasovitsky, Alison Long, Martin Maiden, Morgan Nilsson, Frans Plank, Andrew Spencer, Carole Tiberius, Nigel Vincent, the anonymous referees for Language, associate editor Gregory Stump, and editor Brian Joseph. Special thanks are due to Marina Chumakina, Dunstan Brown, and Andrew Hippisley for fruitful collaboration during the Surrey Morphology Group suppletion project (2000-2003), and since its formal completion. 
I describe a canonical approach, which is then demonstrated for the challenging topic of suppletion (\$1.3). According to Hockett (1958:280), suppletion represents the 'highwater-mark of irregularity', while Dressler (1985c:97) calls it a 'scandal' for theories of morphological naturalness.

The canonical approach means that I take definitions to their logical end point, enabling me to build theoretical spaces of possibilities. Unlike classical typology, only then does one ask how this space is populated with real instances. The canonical instances, that is, the best, clearest, indisputable (the ones closely matching the canon), are unlikely to be frequent. Rather, they are likely to be rare or even nonexistent. As Johanna Nichols (p.c.) puts it: 'Canonical constructions are all alike; each noncanonical construction is noncanonical in its own way'. ${ }^{1}$ Nevertheless, the convergence of criteria fixes a canonical point from which the phenomena actually found can be calibrated, following which there can be illuminating investigation of frequency distributions.

This approach has been worked out for syntax, specifically for the tricky area of agreement (Corbett 2003), and is applied to Miraña in Seifart 2005:156-74 and to Gujarati in Suthar 2006:178-98; this area is developed in Corbett 2006 where twenty criteria define the theoretical space. There is also some preliminary discussion of canonicity in Corbett 2005a. The canonical approach allows the linguist to handle gradient phenomena in a principled way. And there is a nice practical point: when we say that the examples nearest to canonical are 'best', 'clearest', 'indisputable', the last implies that in defining a particular use of a term we should be able to assume it covers the canonical core. In the ideal scenario, differences in use of terms can be specified in terms of how far out from the canonical point different researchers allow given terms to apply.

This article represents an application of the canonical approach to inflectional morphology. ${ }^{2}$ I start from the point where the features and their values are established for the language in question, in other words, analysis of the syntactic part of morphosyntax is well advanced. This is not to minimize the problems; this task can involve complex analytical decisions. If the features and their values are established, these should 'multiply out', so that all possible cells in a paradigm exist. For example, if a given language has four cases and three numbers in its nominal system, the paradigm of a noun should have twelve cells. (This is equivalent to Spencer's notion of EXHAUSTIVITY (2003:252).) Furthermore, to be fully canonical, a paradigm should be 'consistent', according to the requirements given in Table 1 .

$\begin{array}{lcc} & \text { COMPARISON ACROSS CELLS } & \text { COMPARISON ACROSS } \\ \text { COMPOSITION/STRUCTURE } & \text { OF A LEXEME } & \text { LEXEMES } \\ \text { LEXICAL MATERIAL }(\approx \text { shape of stem }) & \text { same } & \text { same } \\ \text { INFLECTIONAL MATERIAL }(\approx \text { shape of } & \text { same } & \text { different } \\ \text { inflection }) & \text { different } & \text { same } \\ \text { OUTCOME }(\approx \text { shape of inflected } & & \\ \quad \text { word }) & \text { different } & \text { different }\end{array}$

TABLE 1. Canonical inflection.

I take this schema apart step by step. There are two levels of comparison: first, take the abstract paradigm gained by multiplying out the features and their values, and then

\footnotetext{
${ }^{1}$ Compare: 'All happy families are alike; each unhappy family is unhappy in its own way' (Lev Tolstoy, Anna Karenina).

${ }^{2}$ This was begun in Corbett 1999 and developed in Baerman et al. 2005:27-35.
} 
look at any single lexeme fitted within this paradigm. The center column is concerned with comparing cell with cell, within a single lexeme. Look at the composition and structure of the cells (left column); suppose the first consists of a stem and a prefix: for this lexeme to have a canonical paradigm, every other cell must be the 'same' in this regard. Finding a suffix, or a clitic, or any different means of exponence would reveal noncanonicity. In terms of the lexical material in the cell, absolute identity is required (the stem should remain the same), but the inflectional material 'should' be different in every cell. The outcome for such a lexeme (last row) is that every cell in its paradigm will realize the morphosyntactic specification in a way distinct from that of every other cell.

The second level of comparison (right column) involves comparing lexemes one with another, within our given language. A canonical system requires that the composition and structure of each cell remain the same, comparing across lexemes. I require that the lexical information be different (I am, after all, comparing different lexemes). However, in the canonical situation, the inflectional material is identical; that is, if the first lexeme marks genitive plural in $-q-a$, so does every other. ${ }^{3}$

The outcome is that every cell of every lexeme is distinct. Such canonical inflection would make perfect sense in functional terms. It achieves the maximum morphological bang for a minimal phonological buck. Every morphosyntactic distinction is drawn unambiguously, for a small amount of phonological material. Furthermore, the system is so simple that item-and-arrangement morphology would be able to account for it.

The real world of inflectional morphology presents dramatic divergence from this canonical situation. And suppletion is as far from the canon as it is possible to get, along the dimension concerned with lexical material. Within the lexeme, the lexical material 'should' be the same when we compare across the cells; suppletion is precisely the case where the lexical material bears no phonological resemblance across cells. ${ }^{4}$ It represents a worst case, and it is this that makes it relevant to the notion 'possible word'.

1.2. Possible wORDS. It is some years since Chomsky suggested that we should investigate the notion 'possible human language'. A part of that project that has been relatively little pursued is to investigate what is a 'possible word' in a human language. ${ }^{5}$ As just noted, suppletion represents an end point of this notion, since it represents inflection with no phonological regularity. But the outer bounds of the notion possible word can be extended still further, since suppletion interacts with other inflectional phenomena, to give lexical items that are unexpected in their degree of irregularity (§5). While my main aim is typological, I intend the schema of possible words to be of help also to psycholinguists since, for good reason, their experiments are often based on the word, and suppletion provides a limiting case.

1.3. A canonical approach to suppletion. I must now ask how a canonical approach can work for suppletion. Given the sketch of inflectional morphology, it is evident that suppletion is noncanonical, since in the canonical situation the lexical material within a lexeme's paradigm remains the same. This offers a typology where both end points are fixed. That is, in addition to having a canonical point, with the less

\footnotetext{
${ }^{3}$ For a possible earlier approach along these lines (of which I was unaware), see the discussion of Humboldt in Vennemann 1972.

${ }^{4}$ It can be thought of as 'canonical uncanonicity' (Bernard Comrie, p.c.).

${ }^{5}$ An exception is the collection edited by Dixon and Aikhenvald (2002).
} 
and less canonical instances radiating outward to approach other phenomena, we have a situation where the least canonical end points can also be fixed.

To develop this typology I start from the important work of Mel'čuk (1994, 2000, 2006:405-67), who provides extensive discussion of the formal characterization of suppletion, to which interested readers are referred. The core of Mel'čuk's definition is this:

for the signs $\mathbf{X}$ and $\mathbf{Y}$ to be suppletive their semantic correlation should be maximally regular, while their formal correlation is maximally irregular ... (1994:358)

This definition depends on an expectation that the two signs are related, and related in a way that makes it reasonable to compare them in order to consider whether they are in a suppletive relationship. Mel'čuk gives a detailed technical account for this, but the key intuition, just given, holds good, whether we accept his view of morphology or not. For instance, we can say that for models that operate with inflectional paradigms, the definition above applies to the cells of such paradigms. Or we may allow it to range over larger domains (see \$2.1).

Mel'čuk's definition proves to be a fine basis for a canonical approach. Starting from his general definition, I can establish dimensions along which the phenomenon may vary. I can point to the 'canonical' or best instances, which in the specific case of suppletion means those that are maximally transparent in semantic terms and maximally opaque in formal terms (cf. Mel'čuk 1994:342). I write ' $a>b$ ' for 'a is a more canonical instance than b'. This then is an unusual typology, both in that it is a typology of extremes, and because it is a typology of lexical items.

1.4. TYPES OF MORPHOLOGICAL THEORY. It is worth clarifying the different approaches to morphology, to make clear the writer's underlying assumptions and to enable readers to identify their own view. To this end, Stump (2001:1-9) gives a helpful typology. He first distinguishes LEXICAL theories from InFERENTIAL theories. In lexical theories, affixes have their own lexical entries, while in inferential theories the systematic relations between a stem and an inflected form are expressed in terms of rules or formulas. There is a second distinction, crosscutting the first, which contrasts incremental and realizational theories. In INCREMENTAL theories, words gain morphosyntactic feature values only together with the relevant exponents. In REALIZATIONAL theories, by contrast, stems are associated with particular sets of morphosyntactic feature values and these license the introduction of the inflectional exponents for them. Since the distinctions are orthogonal, there are four types of theory of inflectional morphology: lexical-incremental, lexical-realizational, inferential-incremental, and inferential-realizational. Stump gives examples of each, and his evaluation (2001:3-12) is that the data point toward inferential-realizational theories, that is the WORD-AND-PARADIGM family of theories (as in Matthews 1972). The current writer supports this view, in work on NETWORK MORPHOLOGY (Corbett \& Fraser 1993, Evans, Brown, \& Corbett 2002, and references there).

A particularly relevant observation about suppletion, for these concerns, is that it occurs frequently. ${ }^{6}$ An investigation of thirty-four languages, chosen to ensure genetic and areal diversity and all with inflectional morphology, found only four with no in-

\footnotetext{
${ }^{6}$ Here I mean frequently across languages. It is also true that some languages are particularly rich sources: Levinson (2007) gives Yélî Dnye as a language with a good deal of suppletion. The Skou languages also show prevalent suppletion (Donohue 2002).
} 
stances of inflectional suppletion, according to our analysis (Brown et al. 2004). ${ }^{7}$ These were Central Alaskan Yup'ik, Tarma Quechua, Kolyma Yukaghir, and Navajo. The relevance of this to the types of morphological theory above is that inferential-realizational theories handle suppletion readily, while it is problematic for others. ${ }^{8}$ The study also makes it clear that suppletion is found widely in the world's languages, and not just in the Indo-European languages from which examples of suppletion are most frequently taken.

2. FitTing SupPletion into a grammatical Description. My primary aim is to give a synchronic typology of suppletion. I need to specify where suppletion fits into grammatical description (\$2.1) since there are differing views on this. I also consider briefly the different diachronic trajectories of suppletion (\$2.2), while making clear that I do not limit the typology according to diachronic criteria.

2.1. Component. Some linguists restrict suppletion to inflectional morphology, while others, including Mel'čuk, allow for suppletion also in derivational morphology. This is not an accident of taste: semantic correlations are typically more regular in inflectional than in derivational morphology, hence the clearer (and for some linguists the only) instances of suppletion will be found in inflectional morphology. Starting from Mel'čuk's definition, the reader will see that the canonical instances of suppletion will be found in inflectional morphology, since here the same semantic distinction is being made across large numbers of items (sometimes across all possible items). Thus canonical examples of suppletion are those like go $\sim$ went.$^{9}$ It is therefore logical, as well as a reflection of practice, to treat suppletion in inflectional morphology as more canonical than in derivational morphology.

Some investigators, such as Mel'čuk, and Markey (1985), additionally allow for suppletion within derivational morphology; this is illustrated in Table 2. ${ }^{10}$

\begin{tabular}{cll} 
& \multicolumn{1}{c}{ MALE ANIMAL } & \multicolumn{1}{c}{ FEMALE ANIMAL } \\
medved' 'bear' & medved-ic-a 'she-bear' \\
MORPHOLOGY & osel 'donkey' & osl-ic-a 'she-donkey' \\
'SUPPLETIVE' DERIVATIONAL & tigr 'tiger' & tigr-ic-a 'tigress' \\
MORPHOLOGY & byk 'bull' & korov-a 'cow'
\end{tabular}

TABle 2. 'Suppletive' derivational morphology in Russian (Mel’čuk 1994:362, 400-401).

\footnotetext{
${ }^{7}$ The list of languages has been expanded to thirty-four here in comparison with earlier publications.

8 'Suppletion then is a very valuable indicator of what might otherwise be only covert signs of the morphosyntactic structure of a language. A model which allows suppletion to be treated on a par with other inflectional formations is therefore to be preferred over one that relegates it to some marginal and arbitrary exception mechanism' (Börjars et al. 1997:159). A footnote refers the reader to Vincent \& Börjars 1996, where there is further interesting discussion of the theoretical importance of suppletion for the syntaxmorphology interface

Suppletion is a particular problem for natural morphology. It is addressed in this framework by Dressler (1985a,b,c, 1986), Bittner (1988), Ronneberger-Sibold (1988), and Wurzel (1990), among others, and a counterview is provided by Werner (1987, 1991); see Fertig 1998 and Nubling 2000:249-77 for discussion and further references.

${ }^{9}$ The completeness of the 'fit' into a single lexeme is emphasized by the matching of these forms right through idiomatic uses, as in he'll go halves with you and he went halves with you.

${ }^{10}$ Of course, there are difficult instances that are part inflectional and part derivational. The example quoted, however, is indisputably derivational.
} 
The example is carefully chosen, and even with this one there are various complications, as Mel'čuk himself points out. With such derivational pairing one typically finds gaps and less than regular semantics.

Some linguists go even further and allow suppletion as a term within lexical semantics. For example, Bhat (1967) talks of lexical suppletion, specifically in 'baby talk'. For the Havyaka dialect of Kannada, he lists twenty-six 'suppletive vocables'; 'cow' is umbe in baby talk as compared with dana in adult speech. But this is no more than items with related semantics and different usages. Any expectation that the two signs should be related $(\S 1.3)$ has no firm basis outside of lexical semantics. Similarly Myhill (2001) treats, for example, say, tell, and ask as suppletive, since in his analysis they are exponents of the semantic primitive SAY. I therefore rank the three components as follows:

$$
\text { inflectional morphology }>\text { derivational morphology }>\text { lexical semantics }
$$

Thus I allow for those who draw the line after inflectional morphology and those who are successively more liberal. For clarity, there are good grounds for limiting suppletion to the more canonical instances, namely in inflectional morphology, which is what I do in this article. It is here that one finds the most regular semantic relations, including identity. These relations, of course, are not always fully regular, as is sometimes believed (see $\$ 3.6$ for discussion). This means that I am operating with a tighter version of Mel'čuk's definition than he does.

Where features given the same name operate in different domains, use of the term suppletion can be seriously misleading. Thus there is (nominal) number of the familiar sort, related to the number of entities. But we also find verbal number (called PLURACTIONAL in the Africanist literature) for quantification over events or participants. ${ }^{11}$ Diagnostics differentiating the two are given in Corbett 2000:243-64, together with extensive sources. Verbal number is often reflected in different lexical items (English stampede versus run gives an idea of the type of opposition). Labeling such instances suppletive has led to some confusion and so is best avoided (Corbett 2000:264). ${ }^{12}$

2.2. TIME AXIs. The focus of this article is synchronic typology, and so the phenomena that fit the definition are included, irrespective of their source. Nevertheless, the origin and development of suppletion deserves a brief look, partly because it is interesting and unexpected, and partly to clarify usage. Indeed, though the criteria are presented with synchrony mainly in mind, they are generally equally applicable to diachrony. However, just within diachrony I distinguish two origins of suppletion: incursion, where outside forms invade a paradigm, and suppletion introduced by sound change, where an originally unified paradigm is split by internal changes (Juge 1999). These are also called COMBINATORY versus DISSIMILATORY suppletion (Plank 1996). Some require the combination of forms with different etymologies (incursion) and do not count the second type (sound change) as suppletion. This is not a distinction available to speakers, and it has no part in a synchronic typology, but this traditional view needs to be borne in mind.

It is natural, perhaps, to imagine that suppletion fills gaps. This is the view implied, for instance, by Isačenko (1962:22-23), who talks of defective lexemes entering into a symbiotic relationship. This suggests that the lexemes involved are defective, and

\footnotetext{
${ }^{11}$ See, for example, Hale et al. 1991 on Hopi and Navajo and Mithun 1988 on Central Pomo.

${ }^{12}$ For additional recent data on verbal number see Collins 2001 and Veselinova 2003:167-94, 2005 b.
} 
that suppletion fixes the problem. ${ }^{13}$ The truth is often somewhat stranger: in examples where extensive textual material allows us to examine the different stages, we frequently find lexemes with a full set of inflectional cells that are invaded by another stem.

A classic example is provided by the history of Russian. In the earliest sources the word for 'eye' is $o k-o$, with the plural $o c ̌-i$, forms that go back to Common Slavonic. In the substantial Uspenskij sbornik of the twelfth to thirteenth centuries we still find just these (and other case forms using the same stems). Very useful sources in the story are the Kabal'nye knigi of the sixteenth and early seventeenth centuries, since they include numerous descriptions of debtors, including their eyes. Here in the singular forms we find the borrowing glaz 'eye' as the stem, with $o \check{c}-i$ as the normal plural (though with also some instances of glaz-a). Thus a complete (that is, nondefective) paradigm has been invaded by the stem glaz, and a suppletive lexeme has arisen. But in modern Russian, the forms are glaz in the singular and glaz- $a$ in the plural (forms of $o k-o$ and $o \check{c}-i$ are rare and stylistically marked). Thus over the course of a few centuries a full lexeme has been invaded by a new singular, and then the paradigm has been leveled, resolving the suppletion. For fuller details see Chumakina et al. 2004, which draws on work by Sokolova (1952) and Unbegaun (1969).

The more familiar example of English $g o \sim$ went is also a particularly interesting one; Wełna (2001) documents how the Old English suppletive lexeme gān 'go', preterite èode 'went', gained a new preterite wente in Middle English, replacing the descendents of $\bar{e}$ ode. Thus the invasive form wente gave a new suppletive lexeme from an old one. There are various accounts in the literature of the rise and maintenance of other particular instances of suppletion: see Tanaka 2002 on West Germanic, Markey 1969 on Swedish, Beckmann 2002 on Low German dialects, Fertig 2000:99-104 on the German of Nuremburg 1356-1619, and Koneckaja 1973 on Germanic in general. Other examples include Rudes 1980 for Romanian, Maiden 1995 for Italian, Maiden 2004 for Romance more generally, Gorbačevskij 1967 on Slavonic, Létoublon 1985 on Greek, and Testen 1997 on Arabic.

In what follows I discuss instances of suppletion equivalently, whether the source is known or unknown, and, if known, whether it is incursion or sound change.

3. Criteria internal to the lexeme. The criteria for my typology fall into two large groups, those where the facts from the individual lexeme (seen against the background of the whole inflectional system) are sufficient (this section), and those where a specific outside comparison or reference to an external factor is required (\$4). Since the criteria may be thought of as different dimensions of the typology, coming together at the canonical point, the structure of these sections is star-shaped. That is, with each subsection I start from the canonical center and move out from it according to the criterion under discussion, before returning to what is canonical for the next criterion.

3.1. Elements involved. The basic elements I consider as potentially suppletive are inflected forms (the exponents of cells in a paradigm). Recall from $\$ 1.1$ that in canonical inflection the realization of different morphosyntactic specifications involves affixes. It follows that suppletion, as a noncanonical phenomenon, involves (at least) substantial change in the stem. In the extreme case, however, it is not possible to distinguish stem and affix, and this gives the first criterion for canonical suppletion.

\footnotetext{
${ }^{13}$ For references to defectiveness and suppletion in Ancient Greek and in Indo-European, and discussion of the issue, see Strunk 1977.
} 


\section{Criterion 1: fused exponence $>$ stem}

The basic notion is that if the suppletive form combines stems and inflection, this is 'more canonically suppletive' $(>)$ than if the form is the stem to which appropriate inflections are added. Thus worse is a more canonical instance of suppletion than better, being more opaque (there is no stem-affix divide), while better may be analyzed as a suppletive stem bett- with the comparative marker $-e r .^{14}$

This criterion relates to maximum formal irregularity in the definition in $\S 1.3$. The intuition that the fused type is more completely suppletive is supported by Werner (1996), who has 'pure suppletion' versus 'inflected suppletion'. Nübling (1998:78-79) talks of 'Segmentierbarkeit' (segmentability) versus 'Nichtsegmentierbarkeit' and makes the point that items with a segmentable affix are 'etwas weniger suppletiv' (somewhat less suppletive) than those without. ${ }^{15}$

There are two other types of element that one might consider including in a typology, one larger and one smaller than the stem. First, Mel'čuk (1983) proposes an example of phrasal suppletion. I suggest below ( $\$ 4.2)$ that this can be analyzed without the need to expand the elements involved to include phrases. Second, some investigators, notably Mel'čuk, include inflectional affixes within the possible suppletive elements. ${ }^{16}$ Thus in Russian some nouns take the dative singular in $-u$ and others in $-e$, and these affixes are treated as being instances of suppletion in some accounts. This view presupposes a lexical approach to morphology, which treats affixes and stems as rather similar (Stump 2001:1-3). In inferential approaches, such as network morphology and PARADIGM FUNCTION MORPHOLOGY (Stump 2001), within the word-and-paradigm family, stems and affixes have different statuses (\$1.4). In these frameworks it makes less sense to discuss suppletion in relation to affixes. Moreover it mixes two very different phenomena. Stem suppletion typically involves a small proportion of lexemes, with all their forms affected (since each has one of the stems). In contrast, the use of different suffixes (as in the Russian brat- $u$ 'brother-SG.DAT' versus sestr-e 'sister-SG.DAT') involves just this one case/number specification, but ranges over all of the declinable nouns of the language. And in practical terms, if affixal suppletion is allowed for, then suppletion ceases to be a special boundary phenomenon requiring specific analysis (and a special term) and rather takes in a substantial proportion of inflectional morphology.

3.2. Phonology of the suppletive elements. This section depends on the part of the definition stating that in suppletion the 'formal correlation is maximally irregular'. The second criterion follows naturally from this.

Criterion 2: full $>$ partial

Compare the examples in 1 and 2 .

(1) go $\sim$ went (full suppletion)

(2) think $\sim$ thought (partial suppletion)

\footnotetext{
${ }^{14}$ I use this familiar example, though some might argue that it is derivational rather than inflectional and therefore not fully canonical in that respect (see Stump 2005 for discussion of the inflectional/derivational status of degrees of comparison). For interesting generalizations about suppletion in the degrees of comparison, see Bobaljik 2006.

${ }^{15}$ We might expect the fused-exponence type to be found just in paradigms where a form is not used for further inflection (e.g. better), but the Russian byt' 'be' is a counterexample (see $\$ 3.2$ below; see also Mel'čuk 1997:25-26, 363 for brief consideration).

${ }^{16}$ Maurice Bloomfield (1925) uses 'suppletion' of different derivational affixes in his account of IndoEuropean suffixes, particularly in Sanskrit. For more recent discussion of suppletion in the Sanskrit verbal system, see Deshpande 1992
} 
Suppletion implies the lack of formal correlation. At its simplest, it could be said that 1 shows suppletion and 2 does not. Or, we may take the requirement to be that there is no rule, no regularity linking the two forms. From that viewpoint, there is no synchronic rule of English linking the forms in 2, so they might be considered suppletive. ${ }^{17}$ Even then, the partial phonological similarity of the forms in 2 means that they are less canonically suppletive than those in 1. I cannot yet draw a watertight division between the two, and while the intuitive point is clear, getting to an acceptable definition, whether in formal or in operational terms, is difficult. The full/partial opposition is also termed strong/weak suppletion (e.g. Nübling 1998:78); see Dressler 1990:36-37 and Nubling 1998, 2000:228-30 for further discussion of the degrees of suppletion. The real issue is whether suppletion is a matter of degree, being the end point of a scale of irregularity, or whether there is a clear cutoff between items that are just irregular on the one hand and suppletive items on the other. One must hope that eventually there will be clear psycholinguistic evidence on this issue.

The next criterion is related to the full/partial distinction, since one type of end point is represented by no realization.

Criterion 3: no overt realization $>$ overt realization

Recall that we are comparing inflected forms (not just affixes). I expect the suppletively related elements to have a phonological form, and treat zero realization, when compared to a phonologically realized form, as showing maximal irregularity. The worst case is no overt realization for one stem (which is a morphological black hole). Consider the Basque copula, shown in Table 3.

$\begin{array}{lll}\text { PERSON } & \text { SINGULAR } & \text { PLURAL } \\ \text { 1st } & \text { n-in-tzen } & \text { g-in-en } \\ \text { 2nd FAMILIAR } & \text { h-in-tzen } & - \\ \text { 2nd } & \text { z-in-en } & \text { z-in-eten } \\ \text { 3rd } & \text { z- } \emptyset \text {-en } & \text { d-ir-en }\end{array}$

TABle 3. Past tense indicative of the Basque copula ezan (Hualde \& de Urbina 2003:213).

Here we have suppletion between $\emptyset$ and -in-, which I treat as 'worse' or more canonical than a lexeme with both suppletive stems overtly realized.

Now consider the Russian verb byt' 'be', with the past tense byl but the present tense as zero. ${ }^{18}$

(3) Tanja by-1-a doma. ${ }^{19}$

Tanya be-PST-F.SG at.home

'Tanya was at home.'

(4) Tanja doma.

Tanya at.home

'Tanya is at home.'

The relationship between byla and $\emptyset$ is 'more suppletive' than that between, say, the corresponding forms of idti 'go' (past feminine singular šla, third singular present tense idet). Interestingly, too, the Russian zero form represents fused exponence since the expected inflections are not realized separately (see $\$ 2.1$ ). Note that having a zero stem

${ }^{17}$ Rules may be devised, however, as in Comrie's witty papers $(1978,1979)$.

${ }^{18}$ For the rise of this zero form under Finno-Ugric influence, see L'Hermitte 1978.

${ }^{19}$ We follow the Leipzig glossing rules (http://www.eva.mpg.de/lingua/files/morpheme.html). Note in particular the following conventions: (i) an element in the gloss that does not correspond to an overt element in the example (i.e. a zero-marked element) is enclosed in square brackets (e.g. ex. 13), and (ii) an inherent, nonovert category like noun gender is enclosed in round brackets in the gloss (e.g. ex. 15). 
is in itself no hindrance to inflection, as seen in Basque. Moreover, in Amele, 'The verb "to give" has no overt verb stem and is realized only by verb suffixation' (Roberts 1987:390, 1997). Also, in Koasati the verb 'give' consists of 'a dative prefix, which cross-references the person to whom something is given, and the classifying suffix $-k a$, which indicates that the actor is cross-referenced by the suffixes of class 3A' (Kimball 1991:102; see also 79, 103-4, 130-31). Nimboran (Anceaux 1965:184) is a rich source of such zeroes.

3.3. Number OF VARIANTS. In a canonical inflectional system, lexical material is expressed by a common stem, while different forms reflect different inflectional information (§1.1). Therefore, the higher the number of different ways in which the common lexical material is reflected, the greater the formal irregularity and the more canonically suppletive the lexeme.

Criterion 4: $\quad$ more variants $>$ fewer variants

All other things being equal, a lexeme with more stems is more canonically suppletive than one with fewer. ${ }^{20}$ Thus in the Kartvelian language Georgian (Hewitt 1995: 446-501, Hippisley et al. 2004:401-7) there is a complex system of tense and aspect. The verb 'give' realizes these using the two suppletive items - jl- and - $c$-. The verb 'do' is more canonically suppletive, having three items (showing a further subdivision of forms), namely -švr-, -zam-, and -kn-. Even better is 'come', with a further subdivision giving the four forms $-d i-$, -val-, -vid-, and -sul-.

For other instances of four-way suppletion, I consider data kindly provided by Alice Harris. In Udi (a member of the Lezgian group within Daghestanian) the verb 'say' has four stems.

(5) $e x$ - in the present and imperfect

$p$ - in the aorist I and II and in the two tenses derived from them, also in the infinitive and masdar (a verbal noun)

$u k^{\prime}$ - in the subjunctive I and II, future I and II

either $u p$ - or $u k^{\prime}$ - in the imperative

See, for instance, the examples in 6-9 (Alice Harris, p.c., and Harris 2002:41-43); the source from which Harris drew the example is given after each.

Udi

(6) ex-nu

say-2sg

'you say'

(Dirr 1928:69, 1.14)

(7) $\mathrm{p}-\mathrm{i}-\mathrm{q}$ 'un $^{21}$

say-AORI-3PL

'they said'

(8) $\mathrm{u}\langle$ ne $\rangle \mathrm{k}^{\prime}-\mathrm{o}^{22}$

$\langle 3 \mathrm{sG}\rangle$ say-FuTI

'she will say'

(Dirr 1928:60, 1.17)

(9) ma up-a

NEG Say-IMP

'do not say'

(Schiefner 1863:xv, 1.6)

(Jeiranišvili 1971:171, 1.1)

\footnotetext{
${ }^{20}$ For all things to be equal the lexemes have to be in the same system, that is, having the same number of cells in the paradigm.

${ }^{21}$ Harris marks ejectives ('), rather than aspirates as in the original sources.

${ }^{22} n e$ is an endoclitic here.
} 
Also in Udi, the basic verb stem for 'directed motion' (that is, meaning 'come' or 'go' when with the appropriate preverb) also has four stems (Alice Harris, p.c., Pančvize 1974:84).

(10) zero in the present and imperfect; also the infinitive and masdar, though there is variation here

$-(a) r$ - or $-c$ - in the aorist I and II, and derived tenses

$-(e) \gamma$ - in the subjunctive I and II, and future I and II

-eke in the imperative

The Welsh and Breton copulas are also multiply suppletive (Hendrick 1996; compare Veselinovič 2003 on Irish). And Donohue (2002:194) gives remarkable data from Dusur, a member of the Skou family, New Guinea. The verb 'hit' has seven different stems, according to the object (three persons, both singular and plural, with the third singular distinguishing masculine and feminine). However, though there is sporadic marking of the object on some verbs, 'hit' represents 'the only systematic marking of the object on the verb in these languages' (Donohue 2002:193). Thus while the example is impressive, it does not function within a system of regular inflectional object marking.

The instances cited clearly show a high degree of formal irregularity and fit that part of the requirement for canonical suppletion.

Let us now examine the distribution of suppletive forms over the paradigm as a whole (§3.4) and then consider the smaller question of competing forms in a single cell $(\$ 3.5)$.

3.4. Distribution of SuPPletive forms within THE PARADigm. Distribution is a central issue for the typology of suppletion. Suppose a lexeme has two or more suppletive stems: what are the possible patterns of distribution? In theory, the stems could follow a morphosyntactic pattern (for example, stem A for one feature value, such as singular, and B for another). They could follow a morphological pattern (stem A where nonsuppletive forms show a particular alternation, and B when they do not). Or finally they could follow a phonological principle (stem A when stem-stressed and B when the stress is on the inflection).

I start by opposing morphosyntactic and morphological distribution. For a formal implementation, Stump (2002:149-53) indicates how network morphology can capture the distinction through its use of two default inheritance hierarchies. ${ }^{23}$ To appreciate the difference, I start with the Russian lexeme in Table 4.

$\begin{array}{lll} & \text { SINGULAR } & \text { PLURAL } \\ \text { NOMINATIVE } & \text { rebenok } & \text { deti } \\ \text { ACCUSATIVE } & \text { rebenka } & \text { detej } \\ \text { GENITIVE } & \text { rebenka } & \text { detej } \\ \text { DATIVE } & \text { rebenku } & \text { detjam } \\ \text { INSTRUMENTAL } & \text { rebenkom } & \text { det'mi } \\ \text { LOCATIVE } & \text { rebenke } & \text { detjax }\end{array}$

TABLE 4. Russian rebenok 'child'.

A reasonable suggestion is that the stems are distributed according to the morphosyntactic feature of number. Conversely, in the light of Romance data (see Table 6 below), the reader might well ask whether this example could be described in purely morphological terms. In other words, we should look for a morphological pattern of which this is an instance. The stem patterns of Russian nouns yield various possibilities, but most

\footnotetext{
${ }^{23}$ I use morphosyntactic versus morphological, as in Stump's (2006) account of heteroclisis. Alternative terms for morphological are MORPHOMIC (Aronoff 1994:22-29) or MORPHOLOGICALLY SYSTEMATIC.
} 


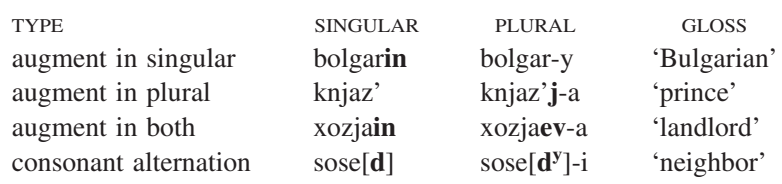

TABLE 5. Some Russian nouns with different stems.

Note: There are other stem patterns, as shown for instance by mat' 'mother', but there are no nouns with corresponding patterns of suppletion.

divide singular from plural, as in Table 5 (for details see Corbett 2000:139-42). In the first three examples in the table there is an augment, while in the last there is an unpredictable alternation of consonant (nonpalatalized $\sim$ palatalized) ${ }^{24}$ The first two examples are representative of small groups of nouns, xozjain 'landlord' is unique, and sosed 'neighbor' is one of a handful of comparable nouns. Together the four types show that there is an established morphological pattern, showing a split between singular and plural. I could then claim that the example in Table 4 also follows this morphological pattern. In this instance the data do not force us to adopt either alternative: I could treat the example as showing a morphosyntactic or a morphological pattern.

In contrast, there are cases in Romance where the distribution of suppletive forms is best seen as being determined by morphological patterns or templates (Matthews 1981, Vincent 1988:297-98, Maiden 1992:306-7, 2003:38-41, Aski 1995, Bonami \& Boyé 2002). ${ }^{25}$ Take the example in Table 6.

$\begin{array}{ccc}\text { PERSON } & \text { SINGULAR } & \text { PLURAL } \\ \text { 1st } & \text { vais } & \text { allons } \\ \text { 2nd } & \text { vas } & \text { allez } \\ \text { 3rd } & \text { va } & \text { vont } \\ \text { TABLE 6. French } & \text { aller 'go' (present tense). }\end{array}$

Stem modifications of different types are frequently found in French verbs, and several follow this pattern of cells (for example, verbs like céder 'give up' have the stem vowel [e] in the first and second persons plural, and $[\varepsilon]$ in the other forms). The important point is that the morphological pattern is established as a part of the morphological system (Maiden 2001), independently of suppletion. ${ }^{26}$ The distribution can be described in terms of morphosyntactic features, but not easily: such a description amounts to listing the cells occupied by one of the stems. And the point is that the same list is an established pattern in the morphological system. Since examples like aller 'go' argue for a morphological distribution of stems, this analysis is a possibility for Russian rebenok 'child' as well. In this case, some would claim that appealing to a morphosyntactic criterion is simpler; in contrast, suppletion is a morphological phenomenon, and it could be argued that therefore a simpler analysis is one that bases it on a morphological pattern. I return to this point below. Thus French aller 'go' is evidence for morphological distribution of stems, while Russian rebenok 'child' could be analyzed as morphological or morphosyntactic. Next I ask whether there are examples that REQUIRE us to invoke

\footnotetext{
${ }^{24}$ The $d$ of sosedi 'neighbors' is palatalized. The $d$ of the nominative singular is devoiced by regular phonological rule; in the genitive (and the accusative syncretic with it), the dative, and the instrumental cases we find the irregular opposition just in palatalization.

${ }^{25}$ For general discussion of suppletion in Romance, see Loi Corvetto 1989.

${ }^{26}$ The full pattern is more complex, since other tenses have to be taken into account. This reinforces the argument being made.
} 
morphosyntactic distribution. I discuss four possible instances of potential evidence for morphosyntactic distribution, but none is incontrovertible.

Arguable instance 1: Number in Slovene. Hippisley and colleagues (2004:401) claimed Slovene as an example, and it looks convincing at first. Consider just the nominative forms (the full six-case paradigm will be needed in $\$ 5.1$ below).

(11) Slovene človek 'man, person'

(Priestly 1993:401)

$$
\begin{array}{cccc}
\text { SINGULAR } & \text { DUAL } & \text { PLURAL } \\
\text { NOMINATIVE } & \text { človek } & \text { človeka } & \text { ljudje }
\end{array}
$$

There are complications to be discussed in $§ 5.1$, but we have a stem primarily for plural versus the remaining forms. This is straightforward in morphosyntactic terms, but it is not a morphological pattern of Slovene. There are several Slovene nouns with two stems, but they typically take the pattern in $12 .{ }^{27}$

(12) Slovene grad 'castle'

(Priestly 1993:402)

$\begin{array}{cccc}\text { SINGULAR } & \text { DUAL } & \text { PLURAL } \\ \text { NOMINATIVE } & \text { grad } & \text { gradova } & \text { gradovi }\end{array}$

Here we have singular versus the remainder. The pattern observed in 11 with človek 'man, person', contrasting plural and the rest, is apparently not found with any other noun. This is not a morphological pattern, but it is easily described in terms of a morphosyntactic feature. While I reported accurately the published accounts, I have since established that the case is not quite so strong. For some speakers at least, the dual can be or must be grada. ${ }^{28}$ It looks as though the argument was valid for the older system, provided it really was as reported, but that the pattern of človek 'man, person' is now shared with other nouns. Data supporting the argument that it should be described in morphosyntactic terms are no longer evident.

Arguable instance 2: Person in Papantla Totonac. There is an interesting set of data that appeared to support the need for morphosyntactic determination and is of sufficient interest to be included here, but is also open to another interpretation. In Papantla Totonac (a member of the Totonac-Tepehua family, centered in Northern Puebla State, Mexico), suppletive stems are distributed according to person as in Table

\begin{tabular}{|c|c|c|c|}
\hline PERSON & SINGULAR & \multicolumn{2}{|c|}{ PLURAL } \\
\hline $1 \mathrm{st}$ & $\mathrm{k}$-an & $\begin{array}{l}\text { EXCLUSIVE } \\
\text { (k)-aná: }\end{array}$ & $\begin{array}{l}\text { INCLUSIVE } \\
\text { aná:-(w) }\end{array}$ \\
\hline 2 nd & pín-a & \multicolumn{2}{|c|}{ piná:-tit } \\
\hline 3 rd & an & \multicolumn{2}{|c|}{$\mathrm{t}-\mathrm{a}^{\prime}: \mathrm{n}$} \\
\hline
\end{tabular}

7. ${ }^{29}$ Here the suppletive relation is specified by person. Moreover, this same suppletion is found in the completive and the perfective (which appears to make it a counterexample to Rudes's claim about verbal suppletion, which is that it will be according to tense/ aspect/mode or by person and number 'inevitably in the present conjugations', 1980: 658). However, it is in the second person that nonphonologically conditioned allo-

\footnotetext{
${ }^{27}$ Other nouns have an augment in all but the nominative singular or in all but the nominative and accusative singular (Priestly 1993:404).

${ }^{28}$ I am grateful to Janez Orešnik, Morgan Nilsson, Aleksandra Derganc, and Teodor Petrič for discussion of this point.

${ }^{29}$ I thank Paulette Levy for these data. We find a similar picture to that of Table 7 in Misantla Totonac (MacKay 1991:226-32).
} 
morphy is found.$^{30}$ Thus Papantla Totonac is more naturally analyzed in morphosyntactic terms, given that the suppletion extends across the incompletive, completive, and perfective, but like the Russian data in Table 4 it could be analyzed in morphological terms.

Arguable instance 3: Case in Russian. Table 8 shows a division between the nominative and the oblique cases, throughout the personal pronouns, which is easily stated in morphosyntactic terms but is not a morphological pattern.

\begin{tabular}{lllllllll} 
& \multicolumn{2}{c}{ 1ST PERSON } & \multicolumn{2}{c}{ 2ND PERSON } & \multicolumn{4}{c}{ 3RD PERSON } \\
& SG & PL & SG & PL & M SG & F SG & N SG & PL \\
NOMINATIVE & ja & my & ty & vy & on & ona & ono & oni \\
ACCUSATIVE & menja & nas & tebja & vas & ego & ee & ego & ix \\
GENITIVE & menja & nas & tebja & vas & ego & ee & ego & ix \\
DATIVE & mne & nam & tebe & vam & emu & ej & emu & im \\
INSTRUMENTAL & mnoj & nami & toboj & vami & im & ej/eju & im & imi \\
LOCATIVE & mne & nas & tebe & vas & nem & nej & nem & nix
\end{tabular}

TABLE 8. The personal pronouns in Russian.

Note: Forms are transliterated from the standard orthography. There are various alternative forms, which are not relevant to the split between nominative and oblique cases.

But the strength of this evidence depends on other assumptions. The case is strongest for those who accept $m y$ 'we' as the plural of $j a$ 'I', $v y$ 'you' as the plural of ty 'thou', and $o n i$ 'they' as the plural of the third person singular pronouns (see Corbett 2005b for discussion, and $\$ 3.6$ below). If each is treated as a separate paradigm, then there is arguably a comparable morphological pattern, that of mat' 'mother', which distinguishes nominative and accusative singular from all other forms singular and plural (which have the stem in mater-); the coincidence of nominative and accusative, rather than of accusative and genitive, in mat' has to do with the syncretic patterns of animacy in Russian (Corbett \& Fraser 1993). So Table 8 provides a good example for those who treat $m y$ 'we' as the plural of $j a$ 'I', and so on, but it is certainly not uncontroversial.

Arguable instance 4: Number and definiteness in East Norwegian. A promising case where syntactic determination appears to be required is found in East Norwegian, discussed in $\$ 3.6$ and $\$ 5.3$ below. Here it is harder to find a relevant morphological pattern.

Let me review the argument so far on the distribution of suppletive stems. There appears to be good evidence for morphological distribution, specifically the French example in Table $6 .{ }^{31}$ There is some evidence for morphosyntactic distribution, though the jury is still out on this. Examples as in Table 4 can be treated as morphological or morphosyntactic, and most apparent instances of morphosyntactic distribution are not fully clear.

I turn now to a third possibility. According to Carstairs-McCarthy (1994:4410), the distribution of suppletive elements will be (morpho)syntactic or phonological. He cites

\footnotetext{
${ }^{30}$ Paulette Levy (p.c.).

${ }^{31}$ Another good example of a morphological pattern is found in Walman (a Torricelli language of Papua New Guinea). According to Lea Brown and Matthew Dryer (p.c.), transitive verbs that take human objects mark the person, number, and gender (and size) of the object according to this pattern: prefixally for first and second persons and for the reflexive, and suffixally or infixally for the various third person combinations. Many verbs that take human objects, perhaps a majority, have two stems, with a highly irregular relation between them; at least one pair is so divergent phonologically as to be on the border of suppletion. The distribution of these two stems in the paradigm is according to the morphological pattern of prefixal versus nonprefixal marking.
} 
examples like Italian and- va(d)- 'go', stating that the suppletion is determined by the stress: $v a(d)$ - is found where the stem is stressed (Carstairs 1988:71, 1990). An account based on stress would also be possible for the French example, as long as we restrict discussion to the present tense; for the rest of the distribution, a (morpho)syntactic account is possible. One could argue that the all-stem appears when there is a stressed inflection in the present or, equivalently, when the form is bisyllabic. Phonological distribution is somewhat problematic conceptually. In order to apply a phonological determinant, we typically need to 'know' the stem. If we appeal to stress, that may itself be treated as a property of the stem. If it is implemented as an independent pattern (as in Brown et al. 1996), then the pattern is most naturally interpreted as part of the morphology. And more generally, if phonological distribution (e.g. by position of stress) is tied to particular cells of the paradigm, then it is really being treated as a morphological pattern. Setting these objections aside, it is worth asking if there are examples that are unambiguous with respect to morphological and phonological distribution.

Consider Table 9, which shows a suppletive relation between the third plural and all of the remaining cells (Rothstein 1993:717, Itkin 2002).

$\begin{array}{ccc}\text { PERSON } & \text { SINGULAR } & \text { PLURAL } \\ \text { 1st } & \text { jestem } & \text { jesteśmy } \\ \text { 2nd } & \text { jesteś } & \text { jesteście } \\ \text { 3rd } & \text { jest } & \text { sa } \\ \text { TABle } & 9 . & \text { Polish być 'be' (present tense). }\end{array}$

There are forms of one, two, and three syllables; the two monosyllabic forms (third person) take different stems. There is no reasonable phonological criterion to account for this distribution. There is, however, a morphological pattern, as shown by other verbs where there is an irregular stem alternation, as with wiedzieć 'know'. Several verbs share the pattern shown in Table 10 (there is another pattern in which first singular and third plural are opposed to the other forms).

$\begin{array}{ccl}\text { PERSON } & \text { SINGULAR } & \text { PLURAL } \\ \text { 1st } & \text { wiem } & \text { wiemy } \\ \text { 2nd } & \text { wiesz } & \text { wiecie } \\ \text { 3rd } & \text { wie } & \text { wiedza } \\ \text { TABLE } & \text { 10. Polish } & \text { wiedzieć 'know' (present tense). }\end{array}$

These Polish data show a distribution according to a morphological pattern, rather than a phonological pattern. And like the French data, they support a morphological rather than a morphosyntactic account. Hence we need to recognize morphological patterns as a possible determiner for the distribution of suppletive stems, and it is not clear whether we need also to recognize phonological determination. The key evidence would be a paradigm where the forms could be determined by some phonological generalization and not by morphological or morphosyntactic regularities. I have not been able to find such an example and conclude tentatively that we do not require phonological determination of suppletion. ${ }^{32}$

To recap, then, Russian rebenok 'child' (Table 4) could in principle be analyzed in two ways, as showing morphosyntactic or morphological distribution. However, French aller 'go' (Table 6) demonstrates morphological rather than morphosyntactic distribu-

\footnotetext{
${ }^{32}$ Andrew Carstairs-McCarthy (p.c.) makes the valid point that excluding affixes from the possible suppletive elements makes it easier to maintain that we do not require phonological determination of suppletive elements.
} 
tion; hence it appears that I have demonstrated the need for morphological distribution. Other examples adduced to support the need to recognize morphosyntactic distribution were indicative but not fully convincing. There was still the possibility that French and similar instances might be analyzed in phonological terms (though there are conceptual problems with this). Polish być 'be' (Table 9), however, is morphological in nature and is not analyzable in phonological terms. The relevant criterion is stated as follows.

Criterion 5: morphological distribution $>$ morphosyntactic distribution

Given that the morphosyntactic instances can generally be seen also as morphological, criterion 5 should be read as indicating that the clearly morphologically determined cases like French (Table 6) and Polish (Table 9) are the most canonical. The link to the general definition is that morphosyntactic determination represents less pure semantic regularity than morphological determination (where there is no possible compromising of semantic regularity). To see why this is so, consider which is more canonically suppletive, French aller, or hypothetical French aller' with the same stem throughout the plural. In the canonical case, the semantic correlation should be maximally regular. In real French the relation between all- and $v a$ - is one of identity; there is no semantic difference at all. Whereas in the hypothetical case, where one stem is singular and the other is plural, there is a very regular relation, but it remains short of full identity.

3.5. Distribution OF SUPPletive FORMS WiTHIN THE CELl. The previous subsection considered the distribution of suppletive stems according to the cells of the paradigm. I now turn to suppletive forms cooccurring within a single cell.

Criterion 6: nonalternating $>$ alternating

There are complex cases where suppletive stems may alternate. This alternation introduces the possibility of less than absolute semantic regularity, which is the link to the main definition. A clear example is Russian čelovek 'person', plural ljudi. ${ }^{33}$ The genitive plural may be čelovek or ljudej.

(13) desjat' čelovek

ten[NOM] person[GEN.PL]

'ten people'

(14) desjat' molod-yx ljud-ej

ten[NOM] young-GEN.PL person-GEN.PL

'ten young people'

These examples have the complicating factor of the condition that determines the alternation (a criterion I return to in $\$ 4.2$ below). Independently of the condition, I consider that in the alternating type the formal relation is less irregular; instead of a sharp distinction of stems, both alternants are able to occur in a particular cell or cells. Further instances of alternating suppletion are noted in Chumakina et al. 2004:288-89.

3.6. Features involved. The overriding consideration here is that oppositions in feature value that are maximally transparent in semantic terms give the canonical instances of suppletion. The closer the two (formally distinct) forms are in meaning, the more canonically suppletive they are. The three criteria to be discussed all fit under this principle. It is particularly important in this section to recall the use of the sign $>$

\footnotetext{
33 There is a little evidence on children's acquisition of this suppletive item. Russian children regularize both ways, so that we find both čelovek $\sim$ čelovek-i and ljud' $\sim$ ljud-i (Dobrova 1993). For notes on the diachrony of this suppletion, see Degtjarev 1982:61-62.
} 
for 'more canonically suppletive than' and not as an indicator of frequency, since we have examples where the two notions are opposed to each other.

Even within a particular feature there can be differences in semantic transparency. The semantics of the number feature vary according to the position of nominals on the animacy hierarchy (Corbett 2000:83-87). This raises the interesting question of whether personal pronouns may be suppletive for number (which depends in part on whether number can be an inflectional feature for pronouns). There is a mismatch of theory and practice here. It is sometimes stated as almost self-evident that we or its equivalent is not the plural of $I$, yet in practice in descriptions of various languages the pronominal paradigms are set out following the pattern of nouns. To make progress, I should pull apart the semantic relation and the frequent formal irregularity of the pronouns. In Corbett 2005b, I suggested that the semantics of number vary in predictable ways according to the ANIMACY HIERARCHY so that the number opposition for pronouns is semantically regular. It is, however, less regular (and the suppletion is therefore less canonical) than instances for some types of noun. Furthermore, there are many examples, from different language families, of personal pronouns showing fully regular inflection for number. Following these two considerations I conclude that suppletion for number in personal pronouns is fully plausible. ${ }^{34}$

I can now turn to the types of feature involved, starting with Bybee's notion of relevance. Bybee (1985:91) defines suppletive paradigms as 'inflectional paradigms that have forms built on two or more stems that are etymologically from different sources'. While it is of interest to test Bybee's suggestions on suppletion generally, one should bear in mind that she is concerned only with the type that arises from different sources (as in $\$ 2.2$ above). Bybee distinguishes categories according to semantic 'relevance', the more relevant affixes being those that affect the meaning of the stem to the greatest extent (1985:4). The point for my discussion is that Bybee claims (1985:92) 'inflectional splits are most likely to coincide with distinctions in the more highly relevant categories'. The most likely categories, for verbs, are in order: aspect, tense, mood, number of subjects or objects, and finally person agreement. And Bybee claims that suppletive paradigms arise from inflectional splits. If we switch focus from likelihood of suppletion being found to the notion of canonicity, I conclude that the more relevant the feature, the lower the semantic regularity, since the interaction with the semantics of the verb root is greatest. The least relevant features are the most regular in semantic terms. Therefore the less relevant the feature involved, the more canonical the suppletion.

\section{Criterion 7: less relevant feature $>$ more relevant feature}

Suppletion according to person agreement, for instance, is more canonical than suppletion according to tense. (Recall again that what is canonical need not be frequent.) This all fits under the general definition, since if we can assign different meanings to the suppletive alternants they are thereby less canonical.

The notion of relevance can be allied to the opposition of contextual and inherent inflection. Booij $(1994,1996)$ draws the distinction as follows: 'Inherent inflection is the kind of inflection that is not required by the syntactic context, although it may have syntactic relevance' (1996:2). An example would be number marking on nouns. Contextual inflection is 'that kind of inflection that is dictated by syntax' (1996:2). Examples include 'agreement markers for adjectives, and structural case markers on

\footnotetext{
${ }^{34}$ For inventories of the features that can be involved, see Mel'čuk 1994:364-72 and Corbett 2001. For data on suppletion for tense and aspect, see Veselinova 2005a.
} 
nouns' (1996:2). If we view the distinction in terms of the features involved, the relation to canonicity is as follows.

\section{Criterion 8: contextual feature $>$ inherent feature}

Since contextual features are externally determined, they are more regular in semantic terms with respect to the lexical semantics of the item inflected; hence the directionality of the criterion is as stated above.

The reader has already seen examples of inherent features determining suppletion, as in the number inflection in Tables 4-6 and ex. 11. Indeed, we might have expected suppletion to be restricted to inherent features (we might have expected that external factors would not have such a dramatic effect on a lexeme as suppletion involves). Yet there are examples of suppletion determined by contextual features. One set comes from Norwegian; I discuss the examples in greater detail below ( $\$ 5.3)$, but at this point exx. 15 and 16 are sufficient to make the point. Hans-Olav Enger provided these examples from Norwegian (East Norwegian dialect).

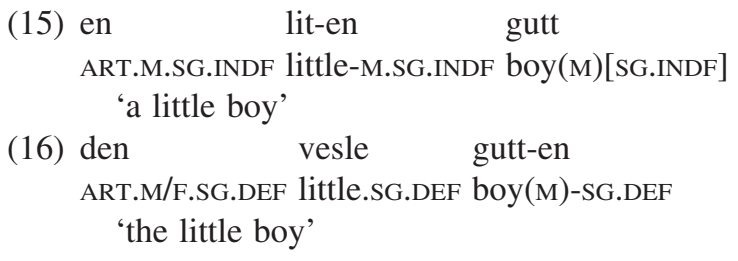

Here the form of the adjective is determined by definiteness, which is a contextual feature for adjectives; it is also not a relevant feature, in Bybee's sense, for adjectives. A further example of suppletion according to a contextual and nonrelevant feature is provided by gender/number agreement in the Daghestanian language Bagwalal (for which see Hippisley et al. 2004:397-98).

This criterion (contextual feature $>$ inherent feature) is the bridge between those criteria internal to the lexeme and those external to it, since inherent features are internal and contextual features have an external source. The link to the main definition is that suppletion according to less relevant and/or contextual features creates greater opacity and is therefore a more canonical, though not a more frequent, instance of suppletion.

While the last two criteria rank features, criterion 9 quantifies them.

Criterion 9: $\quad$ more features $>$ fewer features

For instance, third singular present (as the distribution of one stem) $>$ singular present $>$ present. Where more features are required to specify the cells in which the different stems are found, this lowers the possibility of a semantic distinction (most likely if a single feature is involved), hence the directionality of the criterion. Morphological patterns may need several features in order to characterize them.

4. Criteria external to the lexeme. My second group consists of those criteria where a specific outside comparison or external factor is required.

4.1. Relations with Other LeXemes. I now offer examples where I need to look beyond the lexeme, and I start with overlapping suppletion. The term OvERLAPPING is found in Juge 1999:186 and is adopted for the comparable distribution in heteroclisis by Stump (2006:300-301). Overlapping suppletion can be illustrated from Spanish as in Tables 11. In overlapping suppletion, one set of forms belongs to a second paradigm. If we view the question starting from ir 'go', the preterite forms are also part of the paradigm of ser 'be', and thus they overlap. The relevant criterion is this.

Criterion 10 (preliminary): nonoverlapping $>$ overlapping 


\begin{tabular}{lllll} 
& \multicolumn{2}{c}{ ir 'go' } & \multicolumn{2}{c}{ ser 'be' } \\
& PRESENT & PRETERITE & PRESENT & PRETERITE \\
1SG & voy & fui & soy & fui \\
2SG & vas & fuiste & eres & fuiste \\
3SG & va & fue & es & fue \\
1PL & vamos & fuimos & somos & fuimos \\
2PL & vais & fuisteis & sois & fuisteis \\
3PL & van & fueron & son & fueron
\end{tabular}

TABLE 11. Overlapping suppletion in Spanish (Juge 1999:183).

The overlap makes the semantic regularity within a single paradigm less clear; hence I treat such instances as less fully regular in semantic terms than instances of nonoverlapping suppletion like go $\sim$ went, where synchronically each stem belongs only to this lexeme.

Though we know that diachronically the forms like fui belong to ser, and later invaded voy, the fact that both verbs have suppletive stems means that in synchronic terms the fui forms do not belong to one verb more than the other. I term this nondirectional overlapping. Now suppose that the second item were regular, as is the case in Table 12.

$\begin{array}{lcc} & \text { nemo 'nobody' } & \text { nullus 'none' } \\ \text { NOMINATIVE } & \text { nemo } & \text { nullus } \\ \text { ACCUSATIVE } & \text { neminem } & \text { nullum } \\ \text { GENITIVE } & \text { nullius } & \text { nullius } \\ \text { DATIVE } & \text { nemini } & \text { nulli } \\ \text { ABLATIVE } & \text { nullo } & \text { nullo }\end{array}$

TABLE 12. Overlapping suppletion in Latin (Kennedy 1955:33, 53).

In Table 12 it is evident that the overlapping forms are part of the paradigm of nullus and are taken over into that of nemo. From the perspective of the suppletive paradigm of nemo, I term this DIRECTIONAL OVERLAPPING. This is less canonical than nondirectional overlapping, since the fact that one set of forms is clearly part of another lexical item makes the semantic regularity within the paradigm of nemo even less clear. Thus I rewrite criterion 10 as follows.

Criterion 10: nonoverlapping $>$ nondirectional overlapping $>$ directional overlapping The second type of relation outside the lexeme concerns the existence of REMAINDERS. Starting from the perspective of a complete paradigm, remainders are forms that are more closely related in form than the suppletive stem, but whose semantics do not fit, and so they are not a part of the paradigm. They are 'left over' when the full paradigm is put together. (This is in contrast to criterion 10: criterion 10 concerns instances where there are insufficient forms to build fully independent paradigms, while here we have forms left over.)

Returning to the French verb aller 'go' (Table 6), once I have described the distribution of the suppletive forms within the paradigm, I have given a full account of the use of these stems. There is no more to be said about them; in other words, there are no remainders. In other examples, however, there are further forms requiring analysis (remainders). Lexicologists have had little to say about them, probably since they typically start from semantic considerations (Peter Lutzeier, p.c.). There are helpful hints in Bortnik 1978, and for further discussion see Chumakina et al. 2004. Consider again the Russian paradigm in Table 4 (repeated here). 


$\begin{array}{lll} & \text { SINGULAR } & \text { PLURAL } \\ \text { NOMINATIVE } & \text { rebenok } & \text { deti } \\ \text { ACCUSATIVE } & \text { rebenka } & \text { detej } \\ \text { GENITIVE } & \text { rebenka } & \text { detej } \\ \text { DATIVE } & \text { rebenku } & \text { detjam } \\ \text { INSTRUMENTAL } & \text { rebenkom } & \text { det'mi } \\ \text { LOCATIVE } & \text { rebenke } & \text { detjax }\end{array}$

TABLE 4. Russian rebenok 'child'.

In modern Russian this is the set of forms that functions as a normal paradigm. However, there is also a singular form ditja 'child', which is largely limited to the nominative case and is stylistically restricted. (Its oblique cases were highly irregular, and the plural stem det- is not in a regular correspondence.) Ditja 'child' is not synchronically the singular of deti; it is a 'remainder', an orphaned form without a full paradigm. There is also a plural subparadigm rebjat- $a$ that shows a stem alternation, but one shared by a substantial number of nouns (typically those denoting the young of animals). But these forms do not function as the plural of rebenok 'child'. Rebjata is used of somewhat older groups (males or sometimes mixed) and means 'lads, guys'.

In terms of canonical suppletion, the existence of such remainders makes the semantic correlation between forms like rebenok and deti less than maximally regular, since the remainders with their irregularly related semantics are also in play. Hence the existence of such remainders makes a suppletive pair less canonical than one without.

Criterion 11: no remainders $>$ remainders

As noted, little attention has so far been paid to remainders.

The converse of the problem just discussed is the one in which the formal correlation is not quite maximally irregular. In the canonical instance the formal correlation is completely irregular, and therefore is unique.

Criterion 12: $\quad$ unique $>$ nonunique

If the formal correlation is repeated, the phonological relation is no longer absolutely irregular. Thus, for example, the existence of undergo $\sim$ underwent makes the go $\sim$ went suppletion marginally less canonical than it would be if there were no verb undergo (compare Mel'čuk 1994:388).

4.2. Conditions. Conditions might in principle be InCOMIng (conditions imposed from outside) and OuTGOING (conditions imposed by the suppletive form on other items). In each case I am concerned only with such conditions as they relate to suppletion. ${ }^{35}$

Criterion 13: no outside condition $>$ outside condition

If different forms are subject to an outside condition, this implies that the semantic relation between them may not be fully regular: each is more or less appropriate according to outside conditions. In 13 and 14 above, repeated here as 17 and 18, we saw a paradigm cell where two suppletive variants occur.

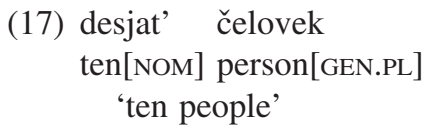

\footnotetext{
35 Thus if in a given language all verbs of particular type impose conditions on argument structure, and one is suppletive, that is not our concern here. I am interested in those instances where the fact of being suppletive would be relevant.
} 
(18) desjat' molod-yx ljud-ej ten[NOM] young-GEN.PL person-GEN.PL

'ten young people'

The conditions that determine the choice are discussed by Bortnik (1978:51-54), Mel'čuk (1985:430-34), and Chumakina and colleagues (2004). The main condition is that if the genitive is governed by a cardinal numeral (or one of certain other quantifiers) AND there is no attributive modifier, then čelovek will be used, otherwise ljudej. This is a less canonical situation than one in which I could simply say that the stem used in the plural is ljud-, except in the genitive plural where it is čelovek. ${ }^{36}$

A well-known case of an outside condition involves the French noun $x u f$ 'egg'. The normative rule is that [œf] is the singular, and the single vowel [ø] is the plural. However, in colloquial French (Swiggers 1985), [ø] appears after [z], thus in many plural contexts, while [œf] appears elsewhere. This is an incoming condition; it may be treated as a shape condition (Pullum \& Zwicky 1988:263). ${ }^{37}$ Note that it is not evidence for phonological determination of suppletion ( $\$ 3.4)$; that distinction related to material within the paradigm, while here suppletion is conditioned from outside. ${ }^{38}$

Once there is the notion of conditions on suppletion, I can tackle the suggested example of suppletion at the phrase level, proposed by Mel'čuk (noted in §3.1). This concerns Russian syn 'son', which has the irregular plural synov'ja. But consider the correspondence in 19 and 20.

(19) suk-in syn

(Russian, Mel’čuk 1983)

bitch-POss[M.SG.NOM] son(M)[SG.NOM]

'son of a bitch'

(20) suk-in-y det-i

bitch-POSS-PL.NOM children-PL.NOM

'sons of bitches'

Mel'čuk suggests that this is an example of phrasal suppletion. But there is an alternative analysis that requires no extension to our typology. Syn 'son' enters into a relation of alternating suppletion with deti 'children' in that in most circumstances it has the irregular plural synov'ja, but under certain conditions it has suppletive deti. This is also a case of overlapping suppletion, since deti is the plural of rebenok 'child' (Table 4). The condition under which the suppletive form deti occurs as the plural of syn is the presence of a negative emotive adjective. The adjective most usually involved is sukin 'of a bitch', as above, but there are several others, like čërtov 'of the devil' (see Mel'čuk 1983:215-16 for a list and some textual examples). Thus we have alternating suppletion, conditioned by the presence of a particular type of adjective within the phrase. This example shows how the different criteria interact, and the example is a particularly complex one. Yet it does not require us to recognize phrasal suppletion. ${ }^{39}$

\footnotetext{
${ }^{36}$ There is a second example in Russian, namely god 'year', which has let as a suppletive stem just in the genitive plural, where it is in alternation with godov. This forms an interesting contrast to čelovek 'person', which has a suppletive stem ljud-in all plural forms, alternating with čelovek just in the genitive plural, while god has the stem god throughout, except that it alternates with let in the genitive plural. See Chumakina et al. 2004 for a detailed account.

${ }^{37}$ While on shape conditions, note the discussion by Tranel (1992) and Lamarche (1996) of the forms of French adjectives, which are sensitive to the presence of an initial vowel in the following word.

${ }^{38}$ The 'paranoid' verbs of Yélî Dnye (Henderson 1995:29-30) can also be treated in this way.

${ }^{39}$ Other instances of conditions on suppletion include the conditions on the appearance of one or another suppletive form of the copula in Welsh and in Breton (Hendrick 1996). The conditions are complex; this is
} 
Having considered incoming conditions, we must now move on to the possibility of outgoing conditions. Different cells of a paradigm do not in canonical examples have differing syntactic effects (except in terms of the features that define those cells). The plural of a noun is not expected to govern a different case as compared to its singular (but we do of course expect it to require plural rather than singular agreement). If I do find outgoing syntactic effects, it is less clear that I am dealing with a single paradigm; hence semantic regularity is less clear. Thus, if there are cases, the criterion is as follows.

Criterion 14: $\quad$ no syntactic effects $>$ syntactic effects

There is a particularly interesting set of data, however, that turns out not to be a case of suppletion (unless purely lexical suppletion is included). I discuss it here as an example of the potential cases that are established, after full consideration, not to be real examples. The example is found in Saliba, a Western Oceanic language of the Suauic family. It has about a thousand speakers on Saliba Island, which is at the eastern tip of Papua New Guinea. The example, carefully documented in Margetts 2007, concerns the verbs $l e$ and mose-i, both meaning 'give'. The verb in Saliba obligatorily takes subject prefixes and object prefixes (when transitive, of course). Margetts claims that the two forms given form a suppletive paradigm. This is suggested by the following example, in which a mother asks her daughter to give her something, and the grandmother concurs.

(21) Mother to child

Kanuwa ku le-ya-ma!

(Saliba, Margetts 2007:§3.1)

sweet.potato 2sG.SUBJ give-3sG.OBJ-hither

'Give me the sweet potato!'

(22) Grandmother to child

Kanuwa ku mose-i- $\emptyset$ !

sweet.potato 2sG.SUBJ give-APP-3sG.OBJ

'Give her the sweet potato!'

(Note that though $k u$ is written separately it is a verbal prefix.) The two verbs have different argument structures, which would be a very interesting syntactic effect of suppletion. The choice of verb, however, is made according to the person of the recipient. The recipient may be encoded on the verb mose-i 'give' as the primary object, and is shown by a directional on the verb le 'give'. Recipient person is not an inflectional category in Saliba, and we are not dealing with canonical suppletion. It is better seen as part of the lexical semantics of the verb; le might be glossed as 'give hither' and mose- $i$ as 'give thither'. There are many somewhat similar instances of different forms for 'give' being used according to the recipient (see Comrie 2002, 2003, Comrie \& Aldai 2002), though few are as complex as Saliba. These fall under lexical semantics: we have two semantically related lexical items (\$2.1). Not finding outgoing conditions on suppletion is expected, in that it is in accord with the principle of morphology-free syntax (Zwicky 1996:301).

5. INTERACTIONS WITH OTHER MORPHOLOGICAL PHENOMENA. When suppletion interacts with other morphological phenomena, the result is lexemes that are challenging for morphological theory, since such interactions bring a further increase in formal irregularity. By 'interaction' I mean more than that a particular lexeme exhibits different

not how the author presents the data, but from the perspective of our typology, it is logical to see the suppletive forms as being determined by the different syntactic contexts. 
phenomena. Rather I intend that these phenomena target the same cells of the paradigm and so interact in this more interesting sense (informally, the irregularity is multiplied rather than just added). It is this interpretation that gives the special interest of such items for defining the notion POSSIBLE WORD. Of the possible interactions I select four particularly interesting types.

5.1. Syncretism. There is a remarkable example of the interaction of suppletion and syncretism, which has been extensively discussed (Plank 1994, Corbett \& Fraser 1997, Evans et al. 2001:215, Baerman et al. 2005:175-77). It involves the Slovene človek 'man person', which was mentioned in $\$ 3.4$ above. The word človek has a suppletive stem in the plural. This interacts with a general rule of Slovene noun morphology, according to which the genitive dual is syncretic with the genitive plural (and the locative dual with the locative plural). In terms of the schema in Table 1, this means that the inflectional material is not different across the cells of the lexeme, and this is noncanonical. The question, then, is what will happen in the genitive and locative dual under these circumstances. The forms are given in Table 13.

\begin{tabular}{llll} 
& SINGULAR & \multicolumn{1}{c}{ DUAL } & PLURAL \\
NOMINATIVE & človek & človeka & ljudje \\
ACCUSATIVE & človeka & človeka & ljudi \\
GENITIVE & človeka & ljudi & ljudi \\
DATIVE & človeku & človekoma & ljudem \\
INSTRUMENTAL & človekom & človekoma & ljudmi \\
LOCATIVE & človeku & ljudeh & ljudeh \\
\hline
\end{tabular}

The pattern of stems is unusual. One interpretation is that syncretism dominates suppletion. The data are also significant in that they provide a strong argument for the need for rules of referral (Evans et al. 2001:215).

Another suppletion-syncretism interaction is shown by the Modern Hebrew demonstrative (Table 14).

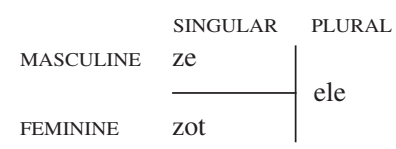

TABle 14. Demonstrative 'this' in Modern Hebrew.

This paradigm shows suppletion and the 'loss' of a formal distinction, that is, syncretism. We would expect, from comparable items in the rest of the system, that this item would have four forms, but the suppletive stem brings with it an unexpected syncretism.

5.2. Periphrasis. Where an inflected form is expected, but in some cases we find the cell filled instead using an additional word, we speak of ANALYTIC or PERIPHRASTIC forms ${ }^{40}$ Thus in Russian we have ležu 'lie' and ležal 'lay' as inflected forms, but budu ležat' 'will lie' as a periphrastic form. A fine interaction of suppletion and periphrasis is found in Romanian dialects. The data are presented by Maiden (2004:240-44), reporting on the Transylvanian linguistic atlas (Noul Atlas Lingvistic Român pe Regiuni; Transilvania, map 1907, unpublished). This particular map gives information on the coming together of a merge 'to go' ( $a$ is the infinitive marker) and a se duce 'to go,

\footnotetext{
${ }^{40}$ While 'periphrasis' is used mainly of the verbal system, Haspelmath (2000:655) points out that we need not restrict the term in this way.
} 
betake oneself', usually used of an animate; this is the reflexive form of a duce 'lead, take'. The present tense forms at Fundătura (point 274 on the atlas) are given in Table 15.

$\begin{array}{lll} & \text { SINGULAR } & \text { PLURAL } \\ \text { 1ST PERSON } & \text { mə duk } & \text { 'merem } \\ \text { 2ND PERSON } & \text { t'e duc } & \text { 'merets } \\ \text { 3RD PERSON } & \text { Sə 'duce } & \text { sə duk }\end{array}$

TABLE 15. Romanian dialect 'go', present tense (Maiden 2004:242).

Here one suppletive stem brings with it periphrastic forms, while the other does not. In terms of the schema in Table 1, this means that the composition/structure of cells is not the same thoughout the paradigm of this lexeme, which is of course noncanonical. Such lexemes suggest strongly that periphrastic forms are indeed morphological objects since they occur in both paradigmatic and syntagmatic opposition to synthetic forms. Note too that in this particular dialect (dialects vary on this point) the pattern in Table 15 is the common one of Romance, discussed in $\$ 3.4$ above. ${ }^{41}$

5.3. OverdifFERENTIATION. Lexemes that have an additional form in their paradigm, like English be, are said to be overdifferentiated (Bloomfield 1933:223-24). I tighten the definition by requiring that the additional form be an additional value of an already attested feature in the class or subclass of the items in question. Thus a typical case of overdifferentiation is that of an element that distinguishes three gender values in a language where normally only two are distinguished. For instance, in the Dravidian language Kolami there are two genders, male human and other, for almost all agreement targets. But the numerals 'two', 'three', and 'four' - and no other agreement targets-have additional forms for female human; these three numerals are said to be overdifferentiated (Emeneau 1955:56, Corbett 1991:168-69). In terms of the schema in Table 1, this involves a comparison across lexemes: the composition of the paradigm is not the same across lexemes (some have an additional cell), which is noncanonical.

I now ask how suppletion can interact with overdifferentiation. In the East Norwegian dialect noted in $\$ 3.4$ and $\S 3.6$, we find these forms for the adjective 'small'. ${ }^{42}$

en lit-en gutt Hans-Olav Enger, p.c.)

ART.M.SG.INDF little-M.SG.INDF boy(M)[SG.INDF]

(Norwegian (East Norwegian dialect), 'a little boy'

(24) den vesle gutt-en

ART.M/F.SG.DEF little.SG.DEF boy(M)-SG.DEF

'the little boy'

(25) ei lit-a jent-e

ART.F.SG.INDF little-F.SG.INDF girl(F)-SG.INDF

'a little girl'

(26) den vesle jent-a

ART.M/F.SG.DEF little.SG.DEF girl(F)-SG.DEF

'the little girl'

\footnotetext{
${ }^{41}$ Vincent and Börjars (1996) investigate the rise of periphrasis in Romance comparatives (adjectives and adverbs). Earlier inflectional forms gave way to periphrastic forms. Thus Latin alt-us 'high, deep', with comparative alt-ior, gives Italian alt-o, with comparative più alt-o. However, the suppletive forms bon-us 'good' with comparative mel-ior were retained. They give rise to Italian buon-o 'good', comparative migliore.

${ }^{42}$ The rise of this suppletion, particularly in terms of number, in different Scandinavian languages but concentrating on Swedish and Danish, is analyzed by Vincent and Börjars (2000); see also Ljunggren 1944.
} 
(27) et lit-e barn

ART.N.SG.INDF little-N.SG.INDF child(N)[SG.INDF]

'a little child'

(28) det

vesle barn-et

ART.N.SG.DEF little.SG.DEF child(N)-SG.DEF

'the little child'

There are three suppletive stems: lit- is in the singular indefinite, vesle is in the singular definite, ${ }^{43}$ and in the plural there is små. This adjective differs from an ordinary adjective in two ways, as Table 16 shows.
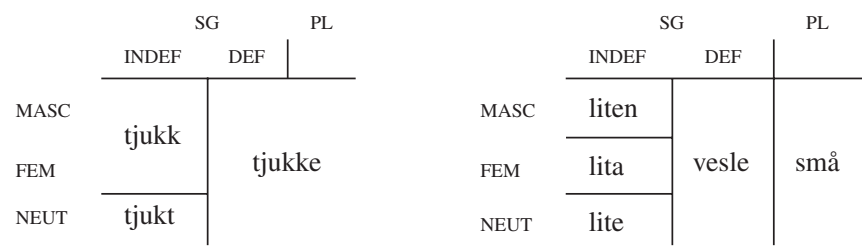

TABLE 16. Regular tjukk 'thick, fat' and liten 'small', East Norwegian (Hans-Olav Enger, p.c.).

First, though the dialect has three genders, shown by the articles, a normal adjective like tjukk 'thick, fat' in the singular makes only one gender distinction, masculine and feminine on the one hand versus neuter on the other.

In contrast, lit- is overdifferentiated, distinguishing masculine (lit-en), feminine (lit$a$ ), and neuter (lit-e) indefinite singular (Enger \& Kristoffersen 2000:104). Here the overdifferentiation is WITHIN one of the suppletive stems. Second, and more interestingly, tjukk 'thick, fat' and other normal adjectives do not distinguish definite plural from definite singular; tjukk-e serves for both. In contrast, vesle is the definite singular, but in the plural små is used. This distinction is not made by tjukk 'thick, fat', and here it is the distinction BETWEEN the suppletive stems that brings about the overdifferentiation. Combining the two means that in the positive, liten has five forms where the typical adjective has three. ${ }^{44}$

As noted in $\$ 3.4$, the distribution of the suppletive forms of liten is another supporting case for distribution according to morphosyntactic features. The overdifferentiated paradigm makes distinctions not found in other adjectives, regular or irregular. The stems

\footnotetext{
${ }^{43}$ In the dialect cited these forms are obligatory. Various other speakers of Norwegian I have asked accept them, but for them vesle is optional.

${ }^{44}$ Mara (Northern Territory, Australia) provides a distant parallel; the following are suppletive (Heath 1981:78).
}

(i) Suppletive items in Mara.

\begin{tabular}{lll} 
& \multicolumn{1}{c}{ SINGULAR/DUAL } & \multicolumn{1}{c}{ PLURAL } \\
'small' & $\begin{array}{l}\text { ygiyu (mainly nonhuman) } \\
\text { ygiyu-ña (mainly human) }\end{array}$ & niriri \\
'big' & $\begin{array}{l}\text { balwayi } \\
\text { gayi (nominative) }\end{array}$ & $\begin{array}{l}\text { ganuganu } \\
\text { wayara }\end{array}$ \\
'other' & -argul (oblique) &
\end{tabular}

The parallel with Norwegian goes a little further than simply involving the corresponding lexical item. In Mara, plural marking is generally restricted to human referents, while these three items mark plurality rigorously for nonhumans as well as humans: this is partly analogous to overdifferentiation, which is found in the Norwegian example. 
are distributed according to the morphosyntactic features of number and definiteness, but when the paradigm is so small, this evidence is not particularly strong.

5.4. Reduplication. Bininj Gun-wok (previously Mayali) shows an interesting interaction of suppletion and reduplication (Evans 2003:386, and p.c.). The verb 'go' has the suppletive stems $w a$ - and re-. They are involved in special left reduplication in the formation of the iterative. (In terms of the schema in Table 1, reduplication implies that inflectional material is not the same across lexemes, which is noncanonical.) This reduplication may be described operationally as follows. First, the inflected form must be monosyllabic for this type of reduplication to be available. The first CV is copied; a nasal is inserted ( $n$ if the root initial is noncoronal, and otherwise $\eta$, which is rendered $n g$ in the practical orthography); then the vowel is copied after the nasal. In some instances, including $r e$-, the glottal stop (rendered $h$ ) is inserted before the reduplication boundary. The effect is seen in the examples in Table 17.

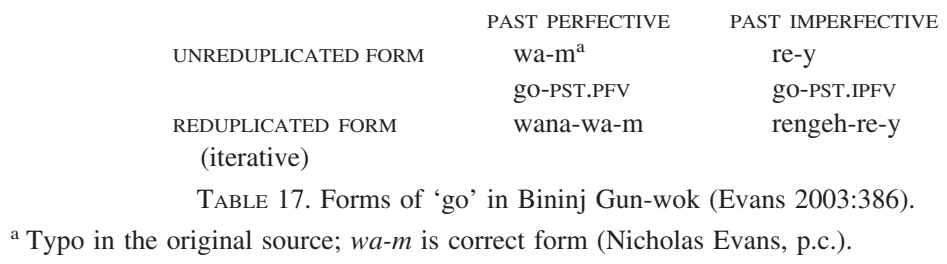

Thus this one suppletive verb has all the properties (that is, the choice of initial consonant and different vowel) sensitive to the different parts of the reduplication rule, and this demonstrates the interaction of suppletion and reduplication.

6. The Role of FReQuency. It is generally accepted that there is a link between irregularity and frequency, as indicated, for instance, by Mańczak (1966) and discussed by Nicholson (1989). In comparing the suppletive items across languages we often find the usual suspects, namely 'be' (Veselinova 2000, Hippisley et al. 2004:412-14), 'go', and 'child'. However, more extensive studies investigating suppletion suggest that the picture is rather more complex than sometimes assumed.

In a detailed study of the distribution of the regular and irregular expression of number in Russian texts, the use of suppletive forms of nouns was included (Corbett et al. 2001, also discussed in Hippisley 2001). In Corbett et al. 2001 we point out that frequency can be viewed in two ways. Given a noun whose singular and plural are in a suppletive relation, what do we expect to be frequent? We could compare lexemes one with another, or we could compare the irregularly related stems within lexemes. The first approach suggests that we should count how many times each lexeme occurs in the plural. This is the ABSOLUTE FREQUENCY of a lexeme's plural. We can compare the absolute frequency of plural of different lexemes, regular, irregular, and suppletive, to see if there is a relationship between suppletive plurals and their absolute frequency. For the second approach we analyze the plural by comparing it, within the lexeme, with the other available forms. For a given lexeme, we can count how often it occurs in the plural as compared with the number of times in the singular. This is the RELATIVE FREQUENCY of the plural. We can then compare the relative frequency of the plural in lexemes where it is suppletive with that in lexemes where it is regular and irregular. In brief, we found that in terms of absolute frequency the three Russian nouns showing suppletion stand out dramatically in that the plural is very frequent. As far as relative frequency is concerned, though the median plural proportion is high, the result is not 
statistically significant. The difficulty is that there are so few nouns with suppletive stems.

A second relevant study was undertaken by Theakston, Lieven, Pine, and Rowland (2002), who investigated the acquisition of $g o$ in English by children between the ages of $2 ; 0$ and 3;0. Though not primarily interested in suppletion, they give data on the use of each of the different forms, and show that the use of particular forms is correlated with different syntactic structures and with different senses (thus they counted up uses like He's gone to school, Does that piece go there?, Where's that book gone?). One of the results is that went was used least frequently of all the forms (2002:794). However, it does not stand out sharply in this respect: goes was also infrequent in comparison with the other forms of the verb (go, going, and gone).

And third, consider Archi, a Nakh-Daghestanian language of the Lezgian group. The plural of nouns is formed by various suffixes; the most regular are given in Table 18.

\begin{tabular}{|c|c|c|c|}
\hline \multicolumn{2}{|c|}{ CONSONANT STEM } & \multicolumn{2}{|c|}{ VOWEL STEM } \\
\hline dab & dab-mul & gimi & gimi-tru \\
\hline $\mathrm{awl}[\mathrm{sG}]$ & awl-PL & boat [sG] & boat-PL \\
\hline 'awl' & 'awls' & 'boat' & 'boats' \\
\hline
\end{tabular}

Now consider these suppletive items.
(29) bič'ni
boždo
corner.of.bag.SG
corners.of.bag.PL
(30) biqI'ni
'corner of a bag, tassel' 'corners of a bag, tassels'
boRIdo ${ }^{4}$
pier.of.bridge.sG pier.of.bridge.PL
'pier of a bridge' 'piers of bridges'

(Archi, Kibrik 1977:46)

I cannot demonstrate the frequency of these items through a textual count, but the fact that I have yet to find another language in which there is a lexical item with the meaning 'corner of a bag' suggests that this is not a frequent item. The term is used of the bottom corners of a bag, which traditionally are decorated with tassels, or of the bottom corners of a sack, which have a tag to make emptying the sack easier. ${ }^{46}$ To confirm that the forms given in 29 and 30 are indeed current, Marina Chumakina kindly checked them during a July 2006 field trip to Archi. Using pictures, she elicited the forms from ten informants, male and female, aged 22 to 82 . With one exception, all gave the forms above. Just one consultant offered bični-te $u$ (the regular form as predicted by Table 18), but then corrected it to boždo. All of the others gave the forms in 29 and 30 without hesitation. ${ }^{47}$ Like the two studies described, this example shows that issues of frequency are not as clear-cut as is often assumed. ${ }^{48}$

\footnotetext{
45 The suppletive forms arose from sound changes that are no longer productive. There is no evidence for a dual in this development.

${ }^{46}$ Marina Chumakina (p.c.).

${ }^{47}$ Kibrik (1977:46) also gives the compound ganga-bič' $i$ 'testicle, ovary', plural ganga-boždo. In the singular, neither part is used independently: the singular is in -bič $i$ (with no -n-). In the plural, the second part, boždo, forms a type of overlapping suppletion relation with bič'ni $\sim$ boždo.

${ }^{48}$ Also relevant here are data from Burmeso, an isolate spoken in the Mamberamo River area of northern Irian Jaya. Donohue (2001:113-15) gives a 'representative list of Burneso nominals', 124 in all. These include, besides arguable cases, the following indisputably suppletive items (given as singular $\sim$ plural): fati $\sim$ kehmet 'male child', jar $\sim$ tafuro 'feces', samo tuguraruro 'machete', timo $\sim$ fihir 'sago tree', ako hiruro 'stone'. As with Archi, we do not have frequency data, but it appears unlikely, at least, that these items are of particularly high frequency, when compared with other more regular items listed.
} 
7. Conclusion. Previous analyses and intuitions have been synthesized into a coherent typology of suppletion. I have demonstrated the value of the canonical approach in typology, by showing how it allows us to tackle an extreme phenomenon. Throughout I have been careful to maintain the distinction between CANONICAL and USUAL or FREQUENT. The criteria, worked out from Mel'čuk's definition along different dimensions, were treated together as internal to the lexeme or external to it; they can also be thought of in terms of the two parts of Mel'čuk's definition, in which case criteria 1-4 together with 12 relate to the formal part, and the remainder to the semantic part. More significant is the fact that the criteria do not conflict; rather they converge. For example, whatever other criteria are in play, having an additional suppletive stem makes the lexeme more canonically suppletive; conversely, whatever else is in play, if the suppletive opposition is shared by another lexeme, that makes it slightly less canonically suppletive. Furthermore, suppletive lexemes may show interactions with other morphological phenomena, making the lexemes in question even less canonical in terms of their inflectional morphology, and more extreme instances of possible words. These remarkable instances of suppletion extend the boundary of possible word. And the canonical approach extends the boundaries of possible typologies.

\section{APPENDIX: RESOURCES FOR RESEARCH INTO SUPPLETION}

The Surrey Suppletion Database (Brown et al. 2004) gives detailed information on suppletion in thirty genetically diverse languages. It is searchable online at http://www.smg.surrey.ac.uk. For each language, suppletion is described in terms of the features involved and the semantic category of the lexical item. The database contains pointers to examples, and there are language reports describing the languages in the database, giving sources and enabling the user to see how decisions were made. There are readme files to help users get started. Those primarily involved were Dunstan Brown, Marina Chumakina, Greville Corbett, and Andrew Hippisley. Several colleagues contributed their time and expertise on particular languages, and we are extremely grateful to them: Willem Adelaar, Nicholas Evans, George Hewitt, Paulette Levy, Marianne Mithun, and Larry Trask. The construction of the database was funded by the Arts and Humanities Research Council under grant number B/RG/AN4375/APN10619; this support is gratefully acknowledged. In addition, an annotated bibliography of suppletion (Chumakina 2004) is available at: http://www.surrey.ac.uk/LIS/ SMG/Suppletion_BIB/WebBibliography.htm

\section{REFERENCES}

Anceaux, Johannes C. 1965. The Nimboran language: Phonology and morphology. (Verhandelingen van het Koninklijk Instituut voor Taal-, Land- en Volkenkunde 44.) The Hague: Martinus Nijhoff.

Aronoff, Mark. 1994. Morphology by itself: Stems and inflectional classes. (Linguistic Inquiry monographs 22.) Cambridge, MA: MIT Press.

Aski, Janice. 1995. Verbal suppletion: An analysis of Italian, French and Spanish to go. Linguistics 33.403-32.

Baerman, Matthew; Dunstan Brown; and Greville G. Corbett. 2005. The syntaxmorphology interface: A study of syncretism. Cambridge: Cambridge University Press.

Beckmann, Werner. 2002. Suppletion im Niederdeutschen. (Niederdeutsche Studien 47.) Cologne: Böhlau.

Bhat, D. N. Shankara. 1967. Lexical suppletion in baby talk. Anthropological Linguistics 9.5.33-36.

BITTNER, ANDREAS. 1988. Reguläre Irregularitäten: Zur Suppletion im Konzept der Natürlichen Morphologie. Zeitschrift für Phonetik, Sprachwissenschaft und Kommunikationsforschung 41.416-25.

BloOMfield, LeONARD. 1933. Language. New York: Holt, Rinehart and Winston.

Bloomfield, Maurice. 1925. On a case of Indo-European suppletive affixes. Language $1.88-95$. 
Bobaljik, Jonathan D. 2006. The ABCs of comparative suppletion. Paper presented at the Jersey Syntax Circle, Princeton, 14 April 2006.

Bonami, Olivier, and Gilles Boyé. 2002. Suppletion and dependency in inflectional morphology. Proceedings of the 8th International Conference on Head-Driven Phrase Structure Grammar, ed. by Frank Van Eynde, Lars Hellan, and Dorothee Beermann, 51-70. Stanford, CA: CSLI Publications. Online: http://cslipublications.stanford.edu/ HPSG/2/hpsg01.html.

Boois, Geert. 1994. Against split morphology. Yearbook of Morphology 1993.27-49.

BOOIJ, GEeRT. 1996. Inherent versus contextual inflection and the split morphology hypothesis. Yearbook of Morphology 1995.1-15.

Borjars, Kersti; Carol Chapman; and Nigel Vincent. 1997. Paradigms, periphrases and pronominal inflection: A feature-based account. Yearbook of Morphology 1996.155-80.

BoRTNIK, NINEL'. 1978. Nekotorye osobennosti osnov, obrazujuščix dvojnye formy množestvennogo čisla. Russian Language Journal 32.112.43-58.

Brown, Dunstan; Marina Chumakina; Greville G. Corbett; and Andrew Hippisley. 2004. The Surrey suppletion database. Online: http://www.smg.surrey.ac.uk/.

Brown, Dunstan; Greville G. Corbett; Norman M. Fraser; Andrew Hippisley; and Alan Timberlake. 1996. Russian noun stress and network morphology. Linguistics 34.53-107.

Bybee, Joan. 1985. Morphology: A study of the relation between meaning and form. (Typological studies in language 9.) Amsterdam: John Benjamins.

CARSTAIRS, ANDREW. 1988. Some implications of phonologically conditioned suppletion. Yearbook of Morphology 1988.67-94.

CARSTAIRS, ANDREw. 1990. Phonologically conditioned suppletion. Contemporary morphology, ed. by Wolfgang U. Dressler, Hans C. Luschutzky, Oskar E. Pfeiffer, and John R. Rennison, 17-23. Berlin: Mouton de Gruyter.

Carstairs-McCarthy, Andrew. 1994. Suppletion. Encyclopedia of language and linguistics, vol. 8, ed. by Ron E. Asher, 4410-11. Oxford: Pergamon.

Chumakina, Marina. 2004. An annotated bibliography of suppletion. Online: http:// www.surrey.ac.uk/LIS/SMG/Suppletion_BIB/WebBibliography.htm.

Chumakina, Marina; Andrew Hippisley; and Greville G. Corbett. 2004. Istoričeskie izmenenija v russkoj leksike: Slučaj čeredujuščegosja suppletivizma. Russian Linguistics 28.281-315.

Collins, Chris. 2001. Aspects of plurality in $\neq$ Hoan. Language 77.456-76.

COMrie, Bernard. 1978. On the go $\sim$ went alternation: A contribution (?) to the generative phonology of English. Lingua pranca, ed. by Tom Ernst and Evan Smith, 59-63. Bloomington: Indiana University Linguistics Club.

Comrie, Bernard. 1979. On being further tempted from go to went. Son of lingua pranca, ed. by Tom Ernst and Evan Smith, 5-6. Bloomington: Indiana University Linguistics Club.

Comrie, Bernard. 2002. Supletivismo según la persona del receptor en el verbo 'dar'. VI Encuentro Internacional de Lingüística en el Noroeste, vol. 2, ed. by Rosa María Ortiz Ciscomani and Zarina Estrada Fernández, 15-35. Hermosillo, Sonora: Editorial UniSon.

Comrie, Bernard. 2003. Recipient person suppletion in the verb 'give'. Language and life: Essays in memory of Kenneth L. Pike, ed. by Mary Ruth Wise, Thomas N. Headland, and Ruth M. Brend, 265-81. Dallas: SIL International and University of Texas at Arlington.

Comrie, Bernard, and Gontzal Aldai. 2002. Suppletion in the Old Basque verb 'to give': A typological perspective. Erramu bonata: Festschrift for Rudolf P. G. de Rijk, ed. by Xabier Artiagoitia, Patxi Goenaga, and Joseba A. Lakarra, 145-51. Bilbao/Bilbo: University of País Vasco/Euskal Herriko University.

Corbett, Greville G. 1991. Gender. Cambridge: Cambridge University Press.

Corbett, Greville G. 1999. Defectiveness, syncretism, suppletion, 'deponency': Four dimensions for a typology of inflectional systems. Paper presented at the second Mediterranean Meeting on Morphology, September 1999, Malta.

Corbett, Greville G. 2000. Number. Cambridge: Cambridge University Press. 
Corbett, Greville G. 2001. Suppletion: Typology, markedness, complexity. Paper presented at the conference Wolfgang Ulrich Wurzel in memoriam: Typologische Aspekte von Markierkeit und Komplexität, Berlin, December 2001. [To appear in On inflection: In memory of Wolfgang U. Wurzel, ed. by Manfred Krifka and Patrick Steinkrüger. Berlin: Mouton de Gruyter.]

Corbett, Greville G. 2003. Agreement: Canonical instances and the extent of the phenomenon. Topics in morphology: Selected papers from the third Mediterranean Morphology Meeting (Barcelona, September 20-22, 2001), ed. by Geert Booij, Janet DeCesaris, Angela Ralli, and Sergio Scalise, 109-28. Barcelona: University Pompeu Fabra. Online: http://www.surrey.ac.uk/LIS/SMG/projects/agreement/.

Corbett, Greville G. 2005a. The canonical approach in typology. Linguistic diversity and language theories (Studies in language companion series 72), ed. by Zygmunt Frajzyngier, Adam Hodges, and David S. Rood, 25-49. Amsterdam: John Benjamins.

Corbett, Greville G. 2005b. Suppletion in personal pronouns: Theory versus practice, and the place of reproducibility in typology. Linguistic Typology 9.1-23.

Corbett, Greville G. 2006. Agreement. Cambridge: Cambridge University Press.

Corbett, Greville G., and Norman M. Fraser. 1993. Network morphology: A DATR account of Russian inflectional morphology. Journal of Linguistics 29.113-42. [Reprinted in Morphology: Critical concepts in linguistics, vol. 6: Morphology: Its place in the wider context, ed. by Francis X. Katamba, 364-96. London: Routledge, 2003.]

Corbett, Greville G., and Norman Fraser. 1997. Vyčislitel'naja lingvistika i tipologija. Vestnik MGU: Serija 9: Filologija 2.122-40.

Corbett, Greville G.; Andrew Hippisley; Dunstan Brown; and Paul Marriott. 2001. Frequency, regularity and the paradigm: A perspective from Russian on a complex relation. Frequency and the emergence of linguistic structure, ed. by Joan Bybee and Paul Hopper, 201-26. Amsterdam: John Benjamins.

Degtjarev, Vladimir I. 1982. Kategorija čisla v slavjanskix jazykax (istoriko-semantičeskoe issledovanie). Rostov-na-Donu: Izdatel'stvo Rostovskogo universiteta.

Deshpande, Madhav M. 1992. Justification for verb-root suppletion in Sanskrit. Historische Sprachforschung 105.1.18-49.

Dirr, AdolPh. 1928. Udische Texte. Caucasica 5.60-72.

Dixon, R. M. W., and Alexandra Y. Aikhenvald (eds.) 2002. Word: A cross-linguistic typology. Cambridge: Cambridge University Press.

Dobrova, Galina. 1993. Morphological characteristics of Russian nouns referring to men in child language: Personal names, professions, terms of family relations etc. (abstract). Crosslinguistic Workshop on the Acquisition of Slavic and Baltic Languages by Children, Cracow, 8-14 July, 1993, 8. Cracow: Jagiellonian University, Department of General and Indo-European Linguistics.

Donohue, Mark. 2001. Animacy, class and gender in Burmeso. The boy from Bundaberg: Studies in Melanesian linguistics in honour of Tom Dutton (Pacific linguistics 514), ed. by Andrew Pawley, Malcolm Ross, and Darrell Tryon, 97-115. Canberra: Pacific Linguistics.

Donohue, Mark. 2002. Which sounds change: Descent and borrowing in the Skou family. Oceanic Linguistics 41.157-207.

Dressler, WolfGang U. 1985a. On the predictiveness of natural morphology. Journal of Linguistics 21.321-37.

Dressler, WolfGang U. 1985b. Sur le statut de la suppléance dans la morphologie naturelle. Langages 78.41-56.

Dressler, Wolfgang U. 1985c. Suppletion in word formation. Historical semanticshistorical word-formation, ed. by Jacek Fisiak, 97-112. Berlin: Mouton de Gruyter.

DRESSLER, WolfGANG U. 1986. Inflectional suppletion in natural morphology. Languages in global perspective, ed. by Benjamin F. Elson, 97-111. Dallas: Summer Institute of Linguistics.

Dressler, WolfGang U. 1990. Sketching submorphemes within natural morphology. Naturalists at Krems: Papers from the Workshop on Natural Phonology and Natural Morphology (Krems, 1-7 July 1988), ed. by Julián Méndez Dosuna and Carmen Pensado, 33-41. Salamanca: University of Salamanca. 
Emeneau, Murray B. 1955. Kolami: A Dravidian language. (University of California publications in linguistics 12.) Berkeley: University of California Press.

Enger, Hans-Olav, and Kristian E. KRISTOFFERSEN. 2000. Innføring i norsk grammatikk: Morfologi og syntaks. Oslo: Landlaget for Norskundervisning/Cappelen Akademisk.

Evans, Nicholas. 2003. Bininj Gun-wok: A pan-dialectal grammar of Mayali, Kunwinjku and Kune. Canberra: Pacific Linguistics.

Evans, Nicholas; Dunstan Brown; and Greville G. Corbett. 2001. Dalabon pronominal prefixes and the typology of syncretism: A network morphology analysis. Yearbook of Morphology 2000.187-231.

Evans, Nicholas; Dunstan Brown; and Greville G. Corbett. 2002. The semantics of gender in Mayali: Partially parallel systems and formal implementation. Language 78.111-55.

FerTIG, DAVID. 1998. Suppletion, natural morphology and diagrammaticity. Linguistics 36.1065-91.

FERTIG, DAVID. 2000. Morphological change up close: Two and a half centuries of verbal inflection in Nuremburg. (Linguistische Arbeiten 422.) Tubingen: Max Niemeyer.

GorbaČEvsKis, A. A. 1967. K voprosu o putjax vozniknovenija suppletivnyx form v slavjanskix jazykax. [Abstract of kandidat dissertation.] Dušanbe: Tadžiksij gosudarstvennyj universitet im. V. I. Lenina.

Hale, Kenneth; LaVerne M. Jeanne; and Paula M. Pranka. 1991. On suppletion, selection, and agreement. Interdisciplinary approaches to language: Essays in honor of S.-Y. Kuroda, ed. by Carol Georgopoulos and Roberta Ishihara, 255-70. Dordrecht: Kluwer.

Harris, Alice C. 2002. Endoclitics and the origins of Udi morphosyntax. Cambridge: Cambridge University Press.

Haspelmath, Martin. 2000. Periphrasis. Morphologie/Morphology: Ein internationales Handbuch zur Flexion und Wortbildung/An international handbook on inflection and word-formation 1, ed. by Geert Booij, Christian Lehmann, and Joachim Mugdan, 654-64. Berlin: Mouton de Gruyter.

Heath, JefFrey. 1981. Basic materials in Mara: Grammar, texts and dictionary. (Pacific linguistics C-60.) Canberra: Department of Linguistics, Research School of Pacific Studies, Australian National University.

Henderson, James. 1995. Phonology and grammar of Yele, Papua New Guinea. (Pacific linguistics B-112.) Canberra: Department of Linguistics, Research School of Pacific and Asian Studies, Australian National University.

Hendrick, Randall. 1996. Some syntactic effects of suppletion in the Celtic copulas. The syntax of the Celtic languages: A comparative perspective, ed. by Robert Borsley and Ian Roberts, 75-96. Cambridge: Cambridge University Press.

Hewitt, B. George. 1995. Georgian: A structural reference grammar. Amsterdam: John Benjamins.

HipPISLEy, ANDREw. 2001. Suppletion, frequency and lexical storage. Chicago Linguistic Society 37.201-14.

Hippisley, Andrew; Marina Chumakina; Greville G. Corbett; and Dunstan Brown. 2004. Suppletion: Frequency, categories and distribution of stems. Studies in Language 28.387-418.

Hockett, Charles F. 1958. A course in modern linguistics. New York: Macmillan.

Hualde, José, and Jon Ortiz de Urbina (eds.) 2003. A grammar of Basque. Berlin: Mouton de Gruyter.

IsaČEnKo, AleKsandr V. 1962. Die russische Sprache der Gegenwart I: Formenlehre. Halle (Saale): Max Niemeyer.

ITKIN, IL'JA B. 2002. K tipologii suppletivnyx paradigm. Paper presented at the third Winter Typological School, Moscow District, 29 January-6 February 2002.

JeIranišVili, Evgeni. 1971. Udiuri ena. [The Udi language.] Tbilisi: Tbilisi University.

Juge, Matthew L. 1999. On the rise of suppletion in verbal paradigms. Berkeley Linguistics Society 25.183-94.

Kennedy, Benjamin H. 1955. The revised Latin primer (ed. and further revised by Sir James Mountford), new impression. London: Longmans, Green and Co. 
KibRiK, AleKsandr E. 1977. Opyt strukturnogo opisanija arčinskogo jazyka, vol. 2: Taksonomičeskaja grammatika. (Publikacii otdelenija strukturnoj i prikladnoj lingvistiki 12.) Moscow: Izdatel'stvo Moskovskogo universiteta.

Kimball, Geoffrey D. 1991. Koasati grammar. Lincoln: University of Nebraska.

Koneckaja, Vera P. 1973. Suppletivizm v germanskix jazykax. Moscow: Nauka.

LAMARCHE, JACQUES. 1996. Gender agreement and suppletion in French. Grammatical theory and Romance languages: Selected papers from the 25th Linguistic Symposium on Romance Languages (LSRL XXV), Seattle, 2-4 March 1995 (Current issues in linguistic theory 133), ed. by Karen Zagona, 145-57. Amsterdam: John Benjamins.

LÉTOUBLON, FrAnÇOISE. 1985. Il allait, pareil à la nuit: Les verbs de mouvement en grec: Supplétisme et aspect verbal. Paris: Klincksieck.

Levinson, Stephen C. 2007. A grammar of Yélî Dnye, the Papuan language of Rossel Island. Nijmegen: Max Planck Institute for Psycholinguistics, to appear.

L'Hermitte, René. 1978. La phrase nominale en russe. Paris: Institut d'études slaves.

LuUngGren, Karl G. 1944. Adjektiven liten och små. Arkiv för nordisk filologi 58.4761.

Loi CoRvetto, Ines. 1989. Anomalie e paradigmi: Il suppletivismo nelle lingue romanze. (Annali della Facoltà di Magistero 34.) Cagliari: University of Cagliari.

MacKay, CARolyn J. 1991. A grammar of Misantla Totonac. Austin: University of Texas at Austin dissertation.

Maiden, Martin. 1992. Irregularity as a determinant of linguistic change. Journal of Linguistics 28.285-312.

Maiden, Martin. 1995. A proposito dell'alternanza esce, usciva, in italiano. Lingua nostra $56.37-41$.

Maiden, Martin. 2001. Sound change, morphemic structure and the rise of suppletion in the Romance verb. Paper presented at the Surrey Linguistic Circle, University of Surrey, 10 May 2001.

MAIDEn, MARTin. 2003. Verb augments and meaninglessness in early Romance morphology. Studi di grammatica italiana 22.1-61.

Maiden, Martin. 2004. When lexemes become allomorphs-On the genesis of suppletion. Folia Linguistica 38.227-56.

MAŃCZAK, Witold. 1966. La nature du supplétivisme. Linguistics 28.82-89.

MargetTs, AnNA. 2007. Learning verbs without boots and straps? The problem of 'give' in Saliba. Cross-linguistic perspectives on argument structure: Implications for learnability, ed. by Melissa Bowerman and Penelope Brown. Mahwah, NJ: Lawrence Erlbaum, to appear.

Markey, Thomas L. 1969. The verbs varda and bliva in Scandinavian: With special emphasis on Swedish. (Studia philologiae Scandinavicae Upsaliensia 7.) Uppsala: Almqvist \& Wiksell.

Markey, Thomas L. 1985. On suppletion. Diachronica 2.51-66.

Matthews, Peter H. 1972. Inflectional morphology: A theoretical study based on aspects of Latin verb conjugation. Cambridge: Cambridge University Press.

Matthews, Peter H. 1981. Present stem alternations in Italian. Logos semantikos: Studia linguistica in honorem Eugenio Coseriu, 1921-1981, vol. 4, ed. by Christian Rohrer, 57-65. Berlin: Walter de Gruyter.

Mel'ČuK, Igor A. 1983. Suppletivologičeskie ètjudy. Russian Linguistics 7.207-18.

MEL'ČUK, IGOR A. 1985. Poverxnostnyj sintaksis russkix čislovyx vyraženij. (Wiener Slawistischer Almanach 16.) Vienna: Institut für Slawistik der Universität Wien.

Mel'ČUK, Igor A. 1994. Suppletion: Toward a logical analysis of the concept. Studies in Language 18.339-410.

Mel'ČUK, IgOR A. 1997. Cours de morphologie générale (théorique et descriptive), vol. 4 : Cinquième partie: Signes morphologiques. Montreal: Les Presses de l'Université de Montréal.

Mel'ČuK, IGOR A. 2000. Suppletion. Morphologie/Morphology: Ein internationales Handbuch zur Flexion und Wortbildung/An international handbook on inflection and wordformation 1, ed. by Geert Booij, Christian Lehmann, and Joachim Mugdan, 510-22. Berlin: Mouton de Gruyter. 
MeL'ČUK, IGoR A. 2006. Aspects of the theory of morphology, ed. by David Beck. Berlin: Mouton de Gruyter. [Ch. 8 is a revision of Mel'čuk 1994.]

Mithun, Marianne. 1988. Lexical categories and number in Central Pomo. In honor of Mary Haas: From the Haas Festival Conference on Native American Linguistics, ed. by William Shipley, 517-37. Berlin: Mouton de Gruyter.

MyнiLl, John. 2001. Suppletion, lexical meaning, semantic primitives, and translation data. Linguistics 39.761-802.

Nicholson, John Greer. 1989. The incidence of suppletion within inflection. Lacus Forum $16.250-59$.

Nübling, Damaris. 1998. Zur Funktionalität von Suppletion. Germanistische Linguistik $141-42.77-101$.

Nübling, Damaris. 2000. Principien der Irregularisierung: Eine kontrastive Analyse von zehn Verben in zehn germanischen Sprache. (Linguistische Arbeiten 415.) Tubingen: Niemeyer.

Osthoff, Hermann. 1899. Vom Suppletivwesen der indogermanischen Sprachen. Heidelberg: Kommissionsverlag von Alfred Wolff.

PANČVIZE, VL. 1974. Uduri enis gramat'ik'uli analizi. [A grammatical analysis of the Udi language.] Tbilisi: Mecniereba.

Plank, Frans. 1994. Homonymy vs. suppletion: A riddle (and how it happens to be solved in ....). Agreement gender number genitive \& (EUROTYP working papers 7/23), 81-86. Konstanz: University of Konstanz.

Plank, Frans. 1996. Patterns of suppletion in inflection. Paper presented at the 7th International Morphology Meeting, University of Vienna, February 16-18, 1996.

Priestly, T. M. S. 1993. Slovene. The Slavonic languages, ed. by Bernard Comrie and Greville G. Corbett, 388-451. London: Routledge.

Pullum, Geoffrey K., and Arnold Zwicky. 1988. The syntax-phonology interface. Linguistics: The Cambridge survey, vol. 1: Linguistic theory: Foundations, ed. by Frederick J. Newmeyer, 255-80. Cambridge: Cambridge University Press.

Roberts, John R. 1987. Amele. London: Croom Helm.

Roberts, John R. 1997. GIVE in Amele. The linguistics of giving, ed. by John Newman, 1-33. Amsterdam: John Benjamins.

Ronneberger-Sibold, ElKe. 1988. Entstehung von Suppletion und Natürliche Morphologie. Zeitschrift fur Phonetik, Sprachwissenshaft und Kommunikationforschung 41.453-62.

Rothstein, Robert A. 1993. Polish. The Slavonic languages, ed. by Bernard Comrie and Greville G. Corbett, 686-758. London: Routledge.

Rudes, BlaIR A. 1980. On the nature of verbal suppletion. Linguistics 18.655-76.

SCHIEFner, A. 1863. Versuch über die Sprache der Uden. (Mémoires de l'Akadémie-impériale des sciences de St.-Pétersbourg 7.6.8.) St. Petersburg: Kaiserliche Akademie der Wissenschaften.

SeIFART, FrAnK. 2005. The structure and use of shape-based noun classes in Miraña (North West Amazon). Nijmegen: Radboud University dissertation.

Sokolova, M. A. 1952. Iz istorii slov osnovnogo slovarnogo fonda russkogo jazyka. Doklady i soobščenija Instituta Jazykoznanija AN SSSR 2.8-19.

SPENCER, ANDREw. 2003. Periphrastic paradigms in Bulgarian. Syntactic structures and morphological information (Interface explorations 7), ed. by Uwe Junghanns and Luka Szucsich, 249-82. Berlin: Mouton de Gruyter.

StrunK, Klaus. 1977. Überlegungen zu Defektivität und Suppletion im Griechischen und Indogermanischen. Glotta 55.2-34.

STUMP, GREGORY T. 2001. Inflectional morphology: A theory of paradigm structure. Cambridge: Cambridge University Press.

Stump, Gregory T. 2002. Morphological and syntactic paradigms: Arguments for a theory of paradigm linkage. Yearbook of Morphology 2001.147-80.

Stump, Gregory T. 2005. Comparison. Lexicology: An international handbook on the nature and structure of words and vocabularies 2, ed. by D. Alan Cruse, Franz Hundsnurscher, Michael Job, and Peter Rolf Lutzeier, 1655-57. Berlin: Mouton de Gruyter.

Stump, Gregory T. 2006. Heteroclisis and paradigm linkage. Language 82.279-322. 
Suthar, Babubhai Kohyabhai. 2006. Agreement in Gujarati. Philadelphia: University of Pennsylvania dissertation.

Swiggers, Pierre. 1985. How to order eggs in French. Folia Linguistica 19.63-66.

Tanaka, Toshiya. 2002. The origin and development of the *es vs. *wes suppletion in the Germanic copula: From a non-Brugmannian standpoint. NOWELE 40(April).3-27.

Testen, David. 1997. The suppletive imperative of Arabic 'come'. Perspectives on Arabic linguistics 10: Papers from the tenth annual Symposium on Arabic Linguistics, ed. by Mushira Eid and Robert R. Ratcliffe, 173-87. Amsterdam: John Benjamins.

Theakston, Anna L.; Elena V. M. Lieven; Julian M. Pine; and Caroline F. Rowland. 2002. Going, going, gone: The acquisition of the verb 'go'. Journal of Child Language $29.783-811$.

TRANel, Bernard. 1992. On suppletion and French liaison. Romance languages and modern linguistic theory: Papers from the 20th Linguistic symposium on Romance languages (LRSL XX), Ottawa, 10-14 April 1990 (Current issues in linguistic theory 91.), ed. by Paul Hirschbühler and Konrad Koerner, 269-308. Amsterdam: John Benjamins.

Unbegaun, Boris. 1969. Les anciens Russes vus par eux-mêmes. Selected papers on Russian and Slavonic philology, by Boris Unbegaun, 272-86. Oxford: Clarendon.

Vennemann, Theo. 1972. Phonetic analogy and conceptual analogy. Schuchardt, the neogrammarians, and the transformational theory of phonological change, ed. by Theo Vennemann and Terence H. Wilbur, 181-204. Frankfurt: Athenäum.

Veselinova, Ludba N. 2000. Suppletion in the paradigms of copula verbs. Cognition and function in language, ed. by Barbara A. Fox, Dan Jurafsky, and Laura A. Michaelis 65-83. Stanford, CA: CSLI Publications.

Veselinova, Ludba N. 2003. Suppletion in verb paradigms: Bits and pieces of a puzzle. Stockholm: Stockholm University dissertation. [Published, Amsterdam: John Benjamins, 2006.]

Veselinova, Ljuba N. 2005a. Suppletion according to tense and aspect. The world atlas of language structures, ed. by Martin Haspelmath, Matthew S. Dryer, David Gil, and Bernard Comrie, 322-25. Oxford: Oxford University Press.

Veselinova, Luuba N. 2005b. Verbal number and suppletion. The world atlas of language structures, ed. by Martin Haspelmath, Matthew S. Dryer, David Gil, and Bernard Comrie, 326-29. Oxford: Oxford University Press.

Veselinovič, ElviRa M. 2003. Suppletion im irischen Verb. (Philologia 55.) Hamburg: Verlag Dr. Kovač.

Vincent, Nigel. 1988. Italian. The Romance languages, ed. by Martin Harris and Nigel Vincent, 279-313. London: Croom Helm/Routledge.

Vincent, Nigel, and Kersti Börjars. 1996. Suppletion and syntactic theory. Papers from the 1st LFG colloquium, Grenoble, August 1996, ed. by Miriam Butt and Tracy Holloway King, 448-62.

Vincent, Nigel, and Kersti BörJars. 2000. The pre-conditions for suppletion. Paper presented at Suppletion 2000: International Workshop on Suppletion, Department of Linguistics, Stockholm University, 26-27 May 2000.

WeEnA, JERZy. 2001. Suppletion for suppletion, or the replacement of éode by went in English. Studia Anglica Posnaniensia 36.95-110.

WERNER, OTMAR. 1987. The aim of morphological change is a good mixture-not a uniform language type. Papers from the 7th International Conference on Historical Linguistics. Pavia, Italy, ed. by Anna Giacalone Ramat, Onofrio Carruba, and Giuliano Bernini, 591-606. Amsterdam: John Benjamins.

Werner, Otmar. 1991. The incorporation of Old Norse pronouns into Middle English: Suppletion by loan. Language contact in the British Isles: Proceedings of the eighth International Symposium on Language Contact in Europe, Douglas, Isle of Man, ed. by Sture Ureland and George Broderick, 369-401. Tübingen: Max Niemeyer.

Werner, OtMAR. 1996. Is suppletion a borderline phenomenon of morphology? Paper presented at the workshop on 'Extragrammatical and marginal morphology' at the 7th International Morphology Meeting, Vienna, February 1996.

Wurzel, Wolfgang U. 1990. Gedanken zu Suppletion und Natürlichkeit. Zeitschrift für Phonetik, Sprachwissenschaft und Kommunikationsforschung 43.86-91. 
Zwicky, ARnold. 1996. Syntax and phonology. Concise encyclopedia of syntactic theories, ed. by Keith Brown and Jim Miller, 300-305. Oxford: Elsevier.

Surrey Morphology Group

[Received 16 August 2005;

Faculty of Human Sciences and Humanities accepted 17 April 2006]

University of Surrey

Guilford, Surrey GU2 7XH

United Kingdom

[g.corbett@surrey.ac.uk] 